UNIVERSIDADE DE SÃO PAULO

Faculdade de Filosofia, Letras e Ciências Humanas

\author{
Érika Salgado
}

\title{
As construções concessivas \\ no Português Brasileiro do século XIX
}

São Paulo

2007 


\section{Érika Salgado}

\section{As construções concessivas}

\section{no Português Brasileiro do século XIX}

Dissertação de mestrado apresentada ao Programa de Pós-Graduação em Filologia e Língua Portuguesa da Faculdade de Filosofia, Letras e Ciências Humanas da Universidade de São Paulo, como exigência parcial para obtenção do grau de Mestre em Letras.

Orientadora: Profa ${ }^{\text {. Dra }}$. Angela C. S. Rodrigues

São Paulo 
AUTORIZO A REPRODUÇÃO E DIVULGAÇÃO TOTAL OU PARCIAL DESTE TRABALHO, POR QUALQUER MEIO CONVENCIONAL OU ELETRÔNICO, PARA FINS DE ESTUDO E PESQUISA, DESDE QUE CITADA A FONTE.

Serviço de Biblioteca e Documentação da Faculdade de Filosofia, Letras e Ciências Humanas da Universidade de São Paulo

As construções concessivas no português brasileiro do século XIX / Érika Salgado; orientadora Angela C. S. Rodrigues. -- São Paulo, 2007.

$93 \mathrm{f}$.

Dissertação (Mestrado - Programa de Pós-Graduação em Filologia e Língua Portuguesa. Área de concentração: Filologia e Língua Portuguesa) - Departamento de Letras Clássicas e Vernáculas da Faculdade de Filosofia, Letras e Ciências Humanas da Universidade de São Paulo.

1. Português do Brasil (Gramática) - Século 19. 2. Gramática funcional - Brasil - Século 19. 3. Escrita (Análise funcional) - Brasil - Século 19. 4. Jornais - Brasil - Século 19. 4. Sociolingüística. I. Título. 


\section{FOLHA DE APROVAÇÃO}

Érika Salgado

As construções concessivas no Português Brasileiro do século XIX

Dissertação de mestrado apresentada ao Programa de Pós-Graduação em Filologia e Língua Portuguesa da Faculdade de Filosofia, Letras e Ciências Humanas da Universidade de São Paulo, como exigência parcial para obtenção do grau de Mestre em Letras.

Aprovado em:

\section{Banca Examinadora}

Profa. Dra. Angela Cecília S. Rodrigues

Instituição: USP

Assinatura:

Prof $^{a}$. Dra ${ }^{\mathrm{a}}$. Odette G. L. A. S. Campos

Instituição: Unesp - Araraquara

Assinatura:

Profa. Dra. Maria Célia P. Lima-Hernandes

Instituição: USP

Assinatura: 
À minha mãe, Nádia, pelo cuidado constante, apoio irrestrito, raciocínio pontual e por ser meu norte na vida.

Aos meus avós Maria e Ozaide, in memoriam, pelo inesquecível amor, acolhimento e pertencimento familiar. 


\section{AGRADECIMENTOS}

À minha orientadora, Profa. Dra . Angela Cecília de Souza Rodrigues, pela disponibilidade, dedicação e incentivo.

À Profa. Dra. Liliane M. Santos, por ensinar-me, entre tantas outras coisas, que o esforço é o diferencial para um "sacrifício por inteiro".

À Profa. Dra . Maria Célia P. Lima-Hernandes e à Profa. Dra . Marilza de Oliveira, pelas valiosas observações no exame de qualificação.

Ao amigo Eduardo, por ser alguém que ainda cultiva e divulga sinceros ideais (que muitas vezes parecem esquecidos!) e, principalmente, por sua pessoa diligente e poética.

Ao amigo Antonio, meu cúmplice confesso, pelo carinho e pela dedicação, e sem os quais as agruras (inclusive idiomáticas) do dia a dia teriam sido ainda maiores.

À recém-doutora Deize Crespim Pereira, pela boa-vontade, disposição, paciência e gentileza na assessoria estatística.

Ao meu pai Oswaldo e à sua companheira Vera, pela contribuição inicial que solidificou os primeiros passos que me conduziram até aqui.

A Deus, pela oportunidade da vida, pela força para superar os obstáculos e por colocar em meu caminho uma torcida incansável. 


\section{RESUMO}

\section{SALGADO, E. As construções concessivas no Português Brasileiro do} século XIX. 2007. 93 f. Dissertação (Mestrado em Língua Portuguesa) Faculdade de Filosofia, Letras e Ciências Humanas, Universidade de São Paulo, São Paulo, 2007.

Nesta dissertação, apresenta-se um estudo descritivo das construções concessivas, consideradas como complexos subordinativos, em jornais brasileiros do século XIX. Os dados foram colhidos em materiais editados para os estudos do Projeto Para História do Português Brasileiro (PHPB), mais precisamente em cartas de leitores e de redatores de jornais oitocentistas do Rio de Janeiro, São Paulo, Paraná, Pernambuco, Bahia e Minas Gerais. Num primeiro momento, foram analisados o grau de formalidade e o gênero dos textos em questão. Em seguida, numa perspectiva funcionalista, buscou-se descrever, analisar e explicar o comportamento das construções concessivas, levando-se em conta: o tipo de conector concessivo utilizado, o valor das construções contrastivas, a correlação modo-temporal, a posição das orações no complexo concessivo, a possibilidade de inversão na ordem das orações, os domínios de leitura, o jogo da polaridade, os tipos de predicação nas duas orações do complexo concessivo. Elementos extra-lingüísticos como o tipo de autor das cartas e o período do século em que foram elaboradas também foram levados em consideração para composição da análise. Desse modo, a descrição do uso das construções concessivas no século XIX tem o propósito de contribuir para os estudos sobre a história do Português Brasileiro.

Palavras-chave: descrição e uso das construções concessivas, imprensa brasileira do século XIX, Português Brasileiro do século XIX, Gramática Funcional. 


\begin{abstract}
SALGADO, E. The concessive constructions in Brazilian Portuguese of the nineteenth century. 2007. 93 f. Dissertação (Mestrado em Língua Portuguesa) - Faculdade de Filosofia, Letras e Ciências Humanas, Universidade de São Paulo, São Paulo, 2007.
\end{abstract}

This dissertation introduces a descriptive study of the concessive constructions, which is considered subornative complexes, in brazilian periodicals of the nineteenth century. The data had been collected in edited materials for studies of Brazilian Portuguese history project (BPHP), more necessarily in readers and periodical editors letters of the nineteenth century, from Rio de Janeiro, São Paulo, Paraná, Pernambuco, Bahia and Minas Gerais. At a first moment, the formality degree and the literal sort had been analyzed. After that, in a functionary perspective, it was tried to describe, analyze and explain the concessive constructions behavior, detaching: the type of the concessive conector used, the value of the contrastive constructions, the correlation manner-time, the position of the conjuncts in the concessive complex, the possibility of changes in the order of the conjuncts, the reading domain, the polarity game, the kind of predicative in both conjunctives of the concessive complex. Extra-linguistics elements, like the kind of the letters author and the period of the century where they had been written, had been also taken in consideration for the compositions of the analysis. In this way, the description of the concessive constructions use, in century nineteen, has the intention to contribute for the studies about the Brazilian Portuguese history.

Key words: description and use of the concessive constructions; brazilian press of the nineteenth century; Brazilian Portuguese of the nineteenth century; Functional Grammar. 


\section{LISTA DE TABELAS}

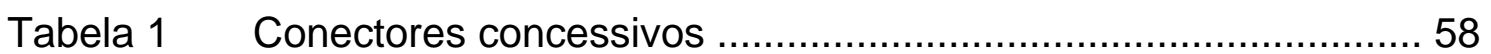

Tabela 2 Classificação das construções contrastivas ............................... 60

Tabela 3 Relação entre tipo de conector e função contrastiva .................. 62

Tabela 4 Posição da oração concessiva .................................................. 63

Tabela 5 Relação entre tipo de conector e posição .................................. 65

Tabela 6 Possibilidade de inversão na ordem das orações ...................... 66

Tabela 7 Domínios de leitura das construções concessivas ..................... 72

Tabela 8 Jogo de polaridade entre as orações nuclear e concessiva ....... 76

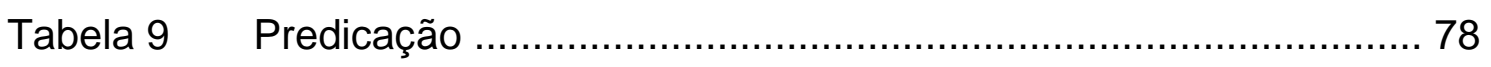

Tabela 10 Tipo de autor e uso de modo verbal ......................................... 85

Tabela 11 Uso do modo subjuntivo no século XIX .................................... 86

\section{GRÁFICO}

Gráfico 1 Graus de formalidade nas cartas de leitores e de redatores ...... 48 


\section{SUMÁRIO}

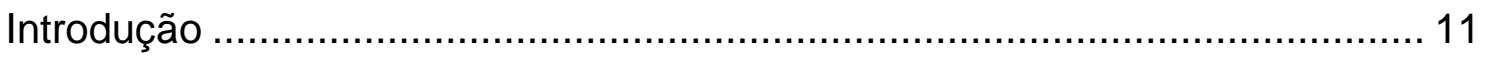

1. Pressupostos teórico-metodológicos...................................................... 14

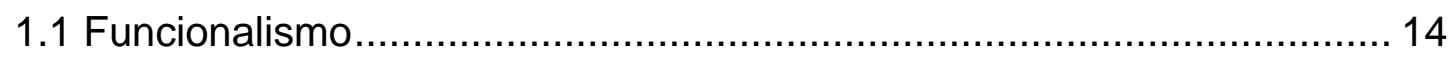

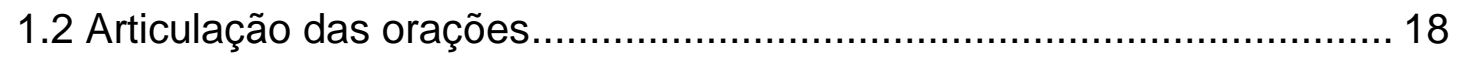

2. As construções concessivas na literatura lingüística.................................. 22

2.1 Gramáticas tradicionais de Língua Portuguesa ................................... 22

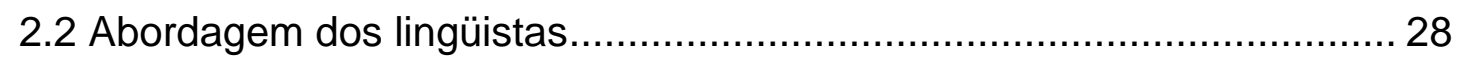

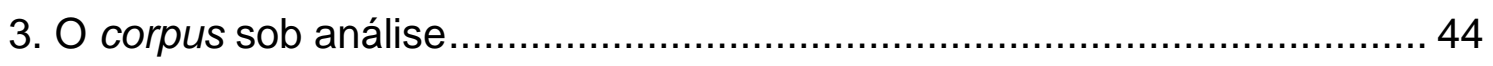

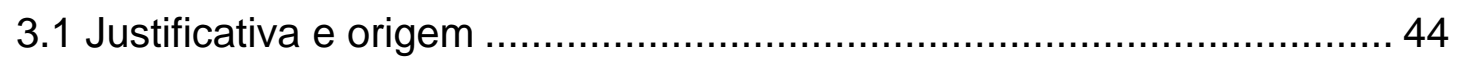

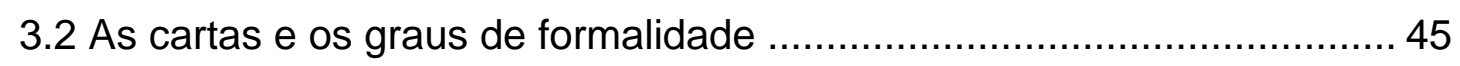

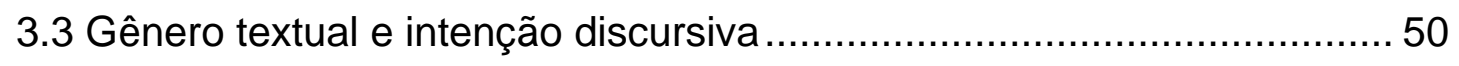

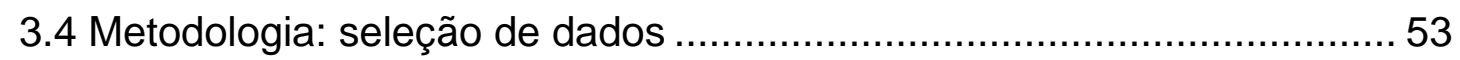

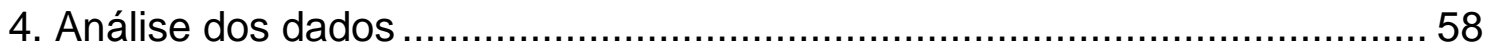

4.1 As construções concessivas acompanhadas de verbo flexionado .......... 58

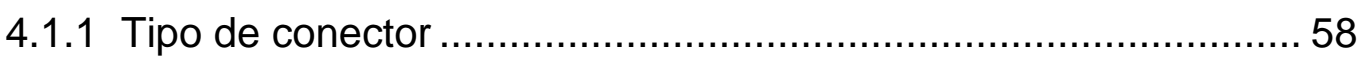

4.1.2 Classificação das Construções Contrastivas ................................ 61

4.1.3 Ordenação do Complexo Concessivo............................................ 63

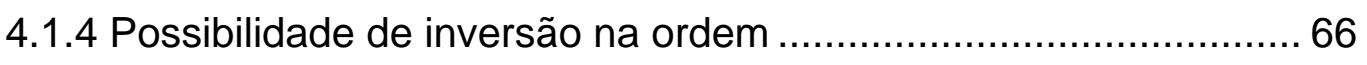

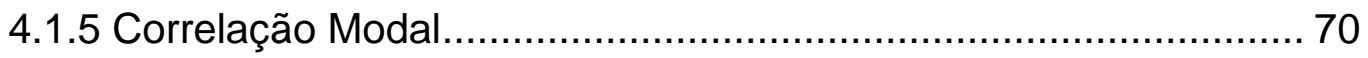

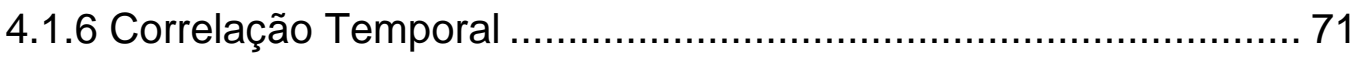

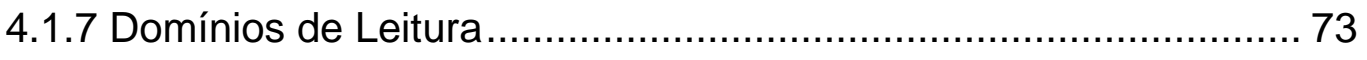

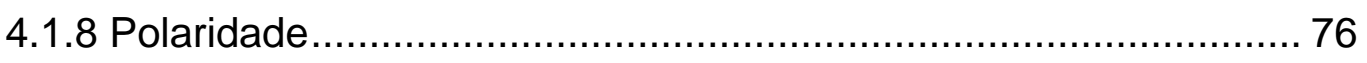

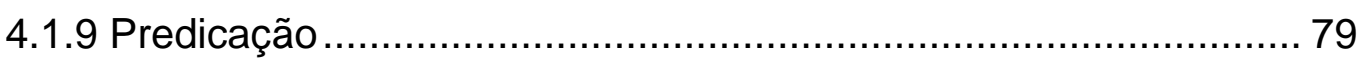

4.2 As construções concessivas sem verbo flexionado …………................ 80

4.3 As construções concessivas e os fatores extra-lingüísticos ................... 85

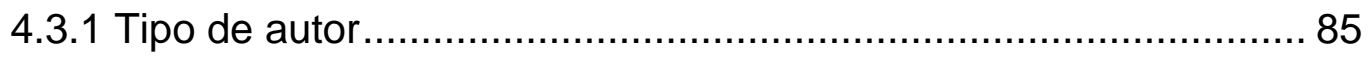

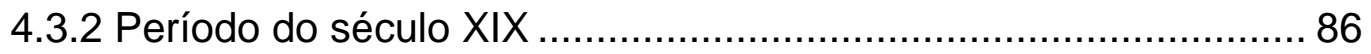

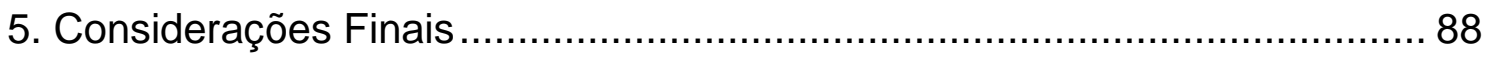

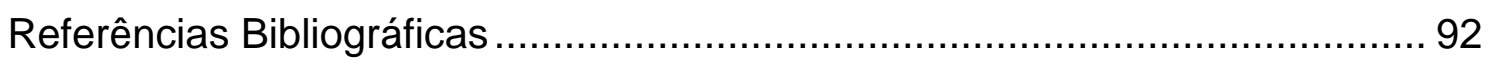




\section{Introdução}

As construções concessivas têm sido estudadas como a junção de uma oração nuclear (principal) e uma oração concessiva (subordinada), sendo a oração concessiva responsável por acrescentar uma contrariedade de expectativa, ou seja, o que foi proposto pela oração nuclear antecipa uma possível refutação de argumentação, encaixando esse tipo de construção nas conexões contrastivas; estabelecem-se, assim, relações entre as construções concessivas e as construções condicionais, as construções causais e as construções adversativas.

Esta dissertação propõe-se a realizar uma descrição do funcionamento das construções concessivas na língua escrita, com base em pressupostos funcionalistas. Sendo assim, optamos por analisar um corpus da modalidade escrita que permitisse verificar como foi o uso e o comportamento das construções concessivas no Português Brasileiro do século XIX.

O Projeto Para a História do Português Brasileiro (PHPB) é a justificativa para o uso desse material e a verificação do fenômeno da concessão na escrita do cidadão brasileiro do século XIX, podendo este estudo contribuir para a elaboração de um panorama histórico do Português Brasileiro (PB).

A investigação do funcionamento das construções concessivas, neste trabalho, ater-se-á às construções concessivas prototípicas, ou seja, com uso de conectores que, tradicionalmente, possuem valor semântico concessivo, assim como à análise da concessão somente, sem examinar os parentescos com construções adversativas, causais ou condicionais.

Com base nos estudos da Lingüística Funcional, que parte do princípio de que a linguagem é, acima de tudo, um instrumento de interação social, sendo, portanto, utilizada para estabelecer uma relação de comunicação entre os falantes da língua, propomo-nos a realizar uma investigação sobre as construções concessivas levando em conta essa premissa básica: a da importância de um estudo do uso lingüístico efetuado para esse fenômeno.

Sendo assim, a perspectiva de uma análise sistêmica na qual seja possível abranger os vários níveis de relação dos elementos lingüísticos mostra-se essencial para atender às necessidades de uma descrição que 
englobe as esferas sintáticas, semânticas e pragmáticas de uma comunicação lingüística. Para isso, utilizamos a teoria geral de Halliday (1994 $\left.{ }^{1}\right)$ que propõe uma inter-relação entre diferentes sistemas lingüísticos.

Considerando, sob a perspectiva funcionalista, que os falantes utilizamse da língua para cumprir determinadas intenções lingüísticas, alguns de nossos questionamentos para o desenvolvimento deste tema foram:

- Que correlações modo-temporais são importantes para a descrição da concessão e são relacionadas ao gênero textual empregado?

- A posição das orações e o jogo de polaridade na construção concessiva revela o tipo de informação que essa construção traz?

- Os domínios de leitura (conteúdo, epistêmico e atos de fala) podem levar a considerações sobre o tipo de processo comunicativo empregado nas construções concessivas?

- O gênero textual, o grau de formalidade e a intenção discursiva são significativos para o uso das construções concessivas?

- Fatores extra-lingüísticos, como o tipo de autor e o período histórico, contribuem para uma melhor caracterização do uso das construções concessivas?

Levando em consideração as hipóteses de análise como norteadoras da pesquisa, organizamos esta dissertação de modo que o primeiro capítulo apresente um panorama da perspectiva teórica funcional adotada, como teoria geral e como teoria específica na articulação das orações.

O segundo capítulo traz uma revisão bibliográfica sobre o que já foi tratado sobre a concessão, tanto nos manuais de gramática normativa, como nos estudos lingüísticos descritivos.

\footnotetext{
${ }^{1} 2^{\mathrm{a}}$ edição.
} 
O perfil do corpus, o tratamento dos dados, a função da carta argumentativa como instrumento do falante para a fala pública são itens que são tratados no terceiro capítulo.

O quarto capítulo contém uma análise quantitativa, o que permite uma observação mais apurada do funcionamento das construções concessivas.

No último capítulo, apontamos os principais pontos da descrição efetuada, assim como a associação sistêmica dos itens estudados. 


\section{Pressupostos teórico-metodológicos}

\subsection{Funcionalismo}

Podemos dizer que existem diferentes abordagens funcionalistas, mas todas convergem para um mesmo princípio, o de uma verificação de como se dá a comunicação eficiente entre os falantes de uma mesma língua.

Essa comunicação eficiente é analisada, na gramática funcional, a partir de uma teoria geral de organização gramatical das línguas naturais, na qual se busca uma integração em uma teoria global de interação social. Por isso, a teoria funcionalista sugere uma descrição na qual seja possível incluir a situação comunicativa, entre o falante e o ouvinte, assim como o estatuto social de ambos dentro da situação de interação determinada socioculturalmente.

Halliday (1994) segue uma diretriz de pesquisa que se baseia na perspectiva de uma teoria lingüística sistêmica, na qual os sistemas estão relacionados pelas funções, uma vez que prioriza os usos da língua.

Esse modelo sistêmico preza não só a interação entre os falantes, mas também o contexto no qual o texto foi produzido, proporcionando uma análise de diferentes níveis para a compreensão do êxito comunicativo.

$\mathrm{O}$ autor considera que existem três aspectos fundamentais para a caracterização de uma gramática funcional:

i) interpretação do texto: considera-se de que forma a língua é usada, pois a linguagem foi criada para satisfazer às necessidades humanas e, para tanto, respeita essas necessidades;

ii) o sistema: as línguas são organizadas em duas formas de significado - reflexiva ou ideacional e interpessoal ou ativa. Esses componentes chamados de metafunções são manifestações no sistema lingüístico de dois propósitos gerais que formam a base de todos os usos da linguagem. Além desses, existe ainda um terceiro componente que é o textual.

iii) os elementos das estruturas lingüísticas: cada parte (oração, frases) é interpretada como funcional ao respeitar o todo. 
Neves (1997, p. 61), apresenta as diferentes vertentes da teoria funcionalista e, ao tratar de Halliday, apresenta sua proposta sobre as funções lingüísticas, que são ativadas no nível gramatical, determinando assim as escolhas feitas em cada um dos sistemas da língua:

\begin{tabular}{|c|c|c|c|}
\hline Sistema & Função & Especificam: & Codificam: \\
\hline Transitividade & Ideacional & $\begin{array}{c}\text { Papéis (ator, } \\
\text { meta, etc.) }\end{array}$ & $\begin{array}{c}\text { Representação } \\
\text { do mundo }\end{array}$ \\
\hline $\begin{array}{c}\text { Modo } \\
\text { (modalidade) }\end{array}$ & Interpessoal & $\begin{array}{l}\text { Funções (sujeito, } \\
\text { complemento, } \\
\text { etc.) }\end{array}$ & Troca \\
\hline $\begin{array}{c}\text { Tema } \\
\text { (informação) }\end{array}$ & Textual & $\begin{array}{l}\text { Relações (dentro } \\
\text { do enunciado; } \\
\text { entre enunciado e } \\
\text { situação) }\end{array}$ & Mensagem \\
\hline
\end{tabular}

Tal perspectiva proporciona uma divisão básica dessa cadeia sistêmica em três itens: sistema de transitividade, sistema de modo e sistema de tema ou informação. Cada um desses sistemas ativa determinadas funções lingüísticas intrínsecas à função textual, divididas em: função ideacional (responsável pelos papéis semânticos e pela coesão); interpessoal (interação sintática) e textual (estruturação da informação).

A função ideacional é aquela na qual o falante e o ouvinte organizam e incorporam na língua sua experiência dos fenômenos do mundo interno (da consciência). Em um outro nível da relação lingüística, ocorre a função interpessoal que se relaciona ao conceito de que o falante utiliza a linguagem como meio de interação no evento lingüístico, no qual estabelece as relações pessoais e sociais. E, num nível mais amplo do funcionamento lingüístico, a função textual vincula-se à própria criação do texto, com sua organização interna e sua relação com o contexto.

Ao aliar essa teoria funcionalista sistêmica ao trabalho aqui apresentado, percebe-se que os conectores concessivos assumem determinados papéis dentro das três diferentes funções no funcionamento sistêmico, sendo eles: 
a. Função textual: no âmbito da oração, os conectores introduzem um comentário, assumindo a função de rema (dado); já no domínio do texto, com uma visão mais geral das informações, percebe-se que a concessão traz uma informação não-recuperável anteriormente no texto e pode ser classificada como tema (novo).

b. Função interpessoal: é a função que permite a identificação da função interacional da linguagem e do falante. Essa função interacional está relacionada à intenção discursiva e, ao se analisarem as cartas de leitores e redatores, que são objeto de estudo deste trabalho, tem-se o falante utilizando o modo persuasivo (quer seja na função concessiva prototípica, quer seja com uma função retificativa) e que se baseia, para ser ativado, em uma provável resposta não-lingüística do falante.

c. Função ideacional: o conector concessivo funciona como um articulador de papéis semânticos no sistema de transitividade, no qual se percebem os processos e relações de atribuição sintática, como a análise que faremos neste trabalho.

Os estudos de Halliday et alii (1964, apud Neves, 1997) já mostravam a discussão sobre o estabelecimento de uma relação sistemática entre a análise lingüística e o contexto de ocorrência dos enunciados. Essa relação sistemática sugerida pelos autores define três componentes metafuncionais do sistema lingüístico, a saber: o campo do discurso (a atividade social implicada associada ao componente experiencial); o teor do discurso (a distância social entre os participantes e ligado ao componente interpessoal); o modo do discurso (o canal entre os participantes e ligado ao componente textual).

Esses conceitos aplicados ao trabalho desenvolvido mostram que o campo do discurso, utilizado como meio para a função social das cartas de redatores e leitores utilizadas, mostram que estas têm, por objetivo primeiro, imporem-se publicamente como um instrumento de ação social. 
O teor do discurso baseia-se no contraponto de esfera pública e esfera privada, pois as relações entre os redatores/leitores e demais leitores dos jornais apresentam-se em dois tipos: comentário sobre algum acontecimento de domínio público ou esclarecimento de alguma circunstância do âmbito privado para o domínio público.

No último item da relação sistemática, temos o modo do discurso permeado pela ação jornalística, sendo o jornal do século XIX o veículo de socialização de acontecimentos para a sociedade da época, funcionando como um integrador social.

Sobre a proposta de análise lingüística apresentada por Halliday e que considera os níveis sintáticos, semânticos e pragmáticos da língua, Neves (1997, p. 75) afirma:

\footnotetext{
Verifica-se, afinal, que Halliday apresenta um modelo altamente elaborado, no qual as diversas noções se sustentam mutuamente, evitando vazios na proposição - que é básica do modo como o significado se codifica nos enunciados efetivos.
}

Os trabalhos de Neves (1999 e 2000) aplicam os fundamentos de uma análise funcionalista de diferentes vertentes, resultando em uma combinação de fatores que possibilita uma ampliação da análise de fenômenos lingüísticos que, para nosso trabalho, funcionou como uma diretriz.

Com tudo isso, pode-se observar que a gramática funcional procura desvendar as seqüências lingüísticas por meio da análise da língua e do falante como pertencentes a um sistema complexo que não se preocupa somente em decoficar mensagens, mas também em compreender a situação de uso.

Tal perspectiva atende às necessidades deste trabalho, visto que as cartas de leitor e de redator dos jornais brasileiros do século XIX são um contexto de uso da argumentação concessiva que extrapola a análise lingüística por ela mesma. 


\subsection{Articulação das orações}

Os processos de combinação das orações têm sido estudados em diferentes perspectivas teóricas e com diferentes objetivos de abordagem. Para a compreensão da relação de interdependência das construções concessivas, analisou-se a caracterização da articulação das orações sob o ponto de vista normativo e sob o ponto de vista descritivo.

Para Cunha e Cintra (1985, p. 578), os processos de combinação das orações são definidos como: composto por coordenação - por serem orações autônomas, independentes, com sentido próprio, sem funcionar como termo de outra oração -, e composto por subordinação, por serem orações sem autonomia gramatical e funcionarem como termos essenciais, integrantes ou acessórios de outra oração.

Bechara (2003) divide os processos de articulação das orações em: subordinação (hipotaxe) e coordenação (parataxe). A hipotaxe remete à chamada oração complexa, pois tem uma função sintática de substantivo, adjetivo ou advérbio, com relação à oração principal.

Segundo o autor, considerou-se o "peso da tradição" para essa definição, o que evidencia o fato de a definição do autor não agregar nenhum outro critério para caracterizar a hipotaxe, salvo pela sugestão da existência de uma "marca de subordinação oracional", representada pela conjunção "que", índice prototípico de subordinação.

Já a parataxe remete a um complexo coordenativo composto por orações sintaticamente independentes entre si o qual pode ser combinado em outros grupos oracionais ou em períodos compostos.

Cunha e Cintra (1985) e Bechara (2003) definem a articulação das orações considerando a dependência ou independência sintática, ponto de vista que será ampliado com a análise dos próximos autores, por considerarem também critérios não só sintáticos, mas também semânticos e pragmáticos.

Halliday (1994, p. 215-224) menciona que as relações de interdependência das orações estão geralmente relacionadas, e não restritas, à classificação das sentenças, pois são sempre complexas: sentença complexa, grupo ou frases complexas, palavra complexa. 
Sendo assim, define essas sentenças complexas em parataxe - que é a ligação de elementos de mesmo valor semântico - e hipotaxe, na qual há a sustentação de elementos de valores não equivalentes, sendo livre o elemento dominante.

A parataxe e a hipotaxe definem um tipo de estrutura que pode ser chamado de univariável, para distingui-la da estrutura multivariável encontrada em outras estruturas. A estrutura multivariável é uma configuração de diferentes relações funcionais: tema-rema ou ator, processo, beneficiário e objetivo (finalizado). Embora essas sejam funções que estejam anexadas, a estrutura realmente consiste nas relações entre elas. A estrutura univariável é a interação de mesma relação funcional.

A relação paratática é lógica, simétrica e transitiva e pode ser exemplificada: (i) relação simétrica: possui alteração de lugar; (ii) relação interativa: combinação dos elementos. Já a relação hipotática é não simétrica e intransitiva, como no enunciado "Eu respiro quando eu durmo", o que não implica dizer "eu durmo quando eu respiro".

Matthiessen e Thompson (1988) sugerem que a articulação das orações não deve ser caracterizada somente no nível da sentença, pois o que distingue uma sentença subordinada de uma sentença principal é o contexto do discurso no qual a sentença em questão aparece.

Os autores afirmam que nenhum estudo já efetuado sobre subordinação tem sido feito sob essa perspectiva e propõem que uma sentença subordinada pode ser vista como uma gramaticalização de uma propriedade geral da estrutura hierárquica do discurso.

A partir do questionamento "Em que a função discursiva motiva a gramática da hipotaxe?", os autores estabelecem uma classificação composta pelos tipos de sentenças e buscam interpretações gramaticais para sentenças combinadas com senso funcional, ou seja, que possam relacionar com função no discurso.

Os autores propõem uma caracterização a partir dos conceitos de Halliday para os estudos das sentenças combinadas, classificadas em hipotaxe e parataxe, que relaciona essas sentenças às circunstâncias (relação circunstancial) de enunciação, como: tempo, condição, causa, concessão, proposição, modo e significado. 
Quando a hipotaxe é realçada, tem-se uma combinação da sentença hipotática que envolve os diversos tipos de relações circunstanciais.

Os graus de interdependência das sentenças são classificados em: projeção versus expansão, elaboração expansiva versus extensão versus intensificação (realce/destaque). Sendo costume analisar somente o grau de interdependência das sentenças, a proposta dos autores é a de que se considere também o realce da hipotaxe e a distinção das categorias para compreensão do discurso.

São as mesmas relações que definem as sentenças combinadas e os textos em geral e, por serem estruturas que se desenvolvem juntas, formam o que os autores definem como "organização retórica do texto". A hipótese é que a combinação de sentenças hipotáticas realçadas envolve gramaticalização de unidades retóricas, como o núcleo-satélite realçado, em certos tipos de discursos ou textos escritos. Em outras palavras, a noção textual motivada pela interdependência da nuclearidade pode ser vista para subordinar a noção gramatical de hipotaxe.

Matthiessen e Thompson ainda consideraram a existência de uma diferença de língua para língua com relação a sua organização retórica e, ainda, que essa organização pode estar sujeita a gramaticalização também.

Para Neves (2002, p. 142), o estudo da articulação das orações sob uma perspectiva da gramática funcional deve considerar uma análise que integre os componentes de produção do enunciado (desde a interação lingüística), o que os estudos de Halliday (1994) e Matthiessen e Thompson (1988) contemplam eficazmente.

De um lado, os estudos de Cunha e Cintra (1985) e Bechara (2003) trazem conceitos canônicos que visam a uma normatização sintática da articulação das orações; por outro lado, os estudos de Halliday (1994) e Matthiessen e Thompson (1988) promovem uma ampliação na noção de articulação das orações, incluindo elementos pragmáticos e semânticos para a análise.

As considerações analisadas sobre a articulação das orações contribuíram para a análise das ocorrências do corpus e a formalização da nomenclatura oração nuclear e oração concessiva que utilizamos, assim 
como para a compreensão do contexto e da "organização retórica" das cartas do século XIX.

Uma última observação com relação à articulação das orações é mencionada por Neves (2002, p. 173):

Em toda essa complexidade a que se liga a atividade de estruturação dos enunciados pelos falantes, ressalta o fato de que existe uma margem muito ampla de liberdade organizacional, suscetível a múltiplas pressões ligadas à necessidade e ao desejo de sucesso na interação, o que se contrabalança, com as restrições internas ao sistema. [...] E o conflito que aparentemente se levanta, não resiste, na verdade, à idéia de que a gramática, afinal, se molda por acomodação, sob pressões de ordem comunicativa, isto é, sob pressões discursivas.

Com tudo isso, torna-se inviável efetuar uma análise da articulação das orações no complexo concessivo, a partir do pressuposto de que tal articulação depende tão somente das frases isoladas, sem relacioná-las ao contexto de enunciação e à intenção discursiva do interlocutor. 


\title{
2. As construções concessivas na literatura lingüística
}

\subsection{Gramáticas tradicionais de Língua Portuguesa}

Os estudos das construções concessivas nas gramáticas tradicionais têm como pressuposto básico o fato de que essas orações fazem parte do complexo subordinativo. Em Said Ali $\left(1964^{2}\right)$, temos a seguinte definição de oração concessiva:

\begin{abstract}
A oração concessiva exprime um fato que, podendo determinar ou contrariar a realização de outro fato principal, deixa entretanto de produzir o esperado ou possível efeito. Esta ocorrência secundária pode ser suposta ou real, e em linguagem antiga distinguia-se pelo emprego ora do conjuntivo, ora do indicativo. Hoje servimo-nos do conjuntivo para um e outro caso. (p. 138)
\end{abstract}

Said Ali já aponta um dos usos das orações concessivas, que é o da conjunção acompanhada de verbo no modo subjuntivo. O autor ainda faz uma outra distinção com relação às características das orações concessivas, ao classificá-las como simples ou intensivas.

As orações concessivas simples (ou comuns) caracterizam-se pela conjunção que trazem (ainda que, ainda quando, embora, conquanto, posto que, mas que, bem que, se bem que, se bem, não obstante que, apesar de que), podendo ainda a oração principal quando posposta, ser realçada por uma partícula correlativa, como contudo, todavia, entretanto, sempre, ainda, assim e outras.

O uso dessas partículas correlativas sugeridas por Said Ali foi documentado nas cartas de leitores e redadores analisadas, como na ocorrência abaixo:

(1) Em fim fiseram se observa-(sic) | com mais sangue frio, multiplicaram-se as utopsias | cadavericas, e o sabio Broussais desenvolveo uma | theoria luminosa, segundo a qual estatue um me- | thodo curativo racional, que numerosos successos | parecem justificar. I| Entretanto ainda que este eloquente professor te- | nha de algum modo demonstrado a natureza, e | a sede da enfermidade, em duas interessantes li- | ções, que serviram para

\footnotetext{
2 3a edição.
} 
attestar a superioridade de I seos conheciementos medicos, todavia elle não me- | teo totalmente o dedo sobre a ferida: estava re- | servado para ontros(sic) Medicos distinctos o accres- | centar mais alguma coisa ás suas observaçoens. (Carta 18 - BA-Salvador/CL/Jornal da Soc. De Agricultura, Commercio, e Industria da Provincia da Bahia/1833)

Na ocorrência (1) a noção de contraste entre as idéias contidas em uma e outra oração do complexo concessivo é realçada, na oração principal posposta à subordinada, por todavia; nas palavras de Said Ali, essa partícula tem função de realce do valor concessivo da oração subordinada.

O autor ainda comenta que nas orações concessivas, o valor de concessão pode ser expresso por que ou quando, desde que o verbo esteja no subjuntivo.

As orações concessivas intensivas referem-se a uma qualidade ou modalidade qualquer, desde que consideradas em grau intensivo e sem limites, como é o caso de construções com expressões como por mais [...] que, por muito $[\ldots]$ que.

Há, ainda, uma outra caracterização das orações concessivas evidenciada por Said Ali, que considera a proposição (a circunstância de enunciação) concessiva, a qual é denominada de "linguagem afetiva" que aparece sem conjunções prototípicas, sendo caracterizadas por expressões como "custe o que custar", "dê onde der", "seja o que for", "aconteça o que acontecer".

Percebe-se que Said Ali buscou relacionar o evento da subordinação ao valor concessivo, por meio da percepção do modo verbal, e também do que chamaremos de "intenção concessiva", mostrando uma preocupação com o valor semântico da oração.

No compêndio gramatical de Rocha Lima $\left(1982^{3}\right)$, as orações adverbiais concessivas aparecem associadas à noção de "oposição":

A oração concessiva expressa um fato - real, ou suposto - que poderia opor-se à realização de outro fato principal, porém não frustrará o cumprimento deste. [...] Do ponto-de-vista da forma, o pensamento concessivo pode representar-se por meio de oração DESENVOLVIDA, ou de oração REDUZIDA. (p. 248)

\footnotetext{
${ }^{3} 22^{\mathrm{a}}$ edição.
} 
Quando desenvolvida, a oração concessiva apresenta uma das conjunções concessivas (ainda que, ainda quando, apesar de que, conquanto, embora, mesmo que, se bem que, sem que) e o verbo no subjuntivo, podendo ainda colocar-se antes ou depois da oração principal.

Em se tratando da posição da oração subordinada concessiva, o autor ainda ressalta que, quando anteposta, há um maior realce no contraste de idéias, conceito este que conflui para o senso-comum de exemplificação de orações concessivas, como no exemplo: "Embora se esforce muito, I (ainda assim, mesmo assim, entretanto) não progride na vida." (Rocha Lima, 1982, p. 249).

Rocha Lima (1982), assim como Said Ali (1964) atribuem um valor concessivo à conjunção que, salientando que é uma conjunção empregada como concessiva, sem contudo iniciar a oração, necessitando assim de auxílio de um predicativo ou de uma locução, como por mais... que, por muito... que, por pouco... que e por... que.

Se a oração concessiva for do tipo reduzida, apresenta-se pelo gerúndio, como o exemplo "Não sendo médico, ele faz, todavia, curas milagrosas" (op. cit., p, 250) ou pelo infinitivo regido de uma das locuções, como: apesar de, não obstante, sem embargo de, a despeito de.

Os estudos de Rocha Lima também apontam para a definição canônica da oração concessiva, como um complexo subordinativo composto por oração principal e subordinada introduzida por conjunção (ou locução conjuntiva) e verbo no modo subjuntivo; o verbo também pode aparecer no gerúndio e no infinitivo, nas orações reduzidas.

Macambira $\left(1978^{4}\right)$ faz uma abordagem das conjunções, entre elas a concessiva, sob os aspectos morfológico e sintático. Visto que o objeto de estudo do autor não era o de analisar as relações sintáticas mais complexas, entre elas a oração concessiva, atemo-nos a buscar as informações sobre as conjunções e suas particularidades para o estudo das orações concessivas.

A análise das conjunções é feita pelo autor sob três aspectos: mórfico, sintático e semântico. A partir da definição de Macambira, "conjunção subordinativa é a que figura em oração cujo verbo esteja, ou possa estar, no

\footnotetext{
${ }^{4} 3^{\mathrm{a}}$ edição.
} 
modo subjuntivo" (1978, p. 67), percebe-se uma interpretação generalizada do autor sobre os elementos que compõem o complexo subordinativo, incluindo as conjunções.

Macambira (1978) define que uma conjunção, para ser classificada como coordenativa ou subordinativa, é necessário verificar a forma do verbo que a acompanha, por exemplo, se o verbo estiver flexionado no subjuntivo, a conjunção é subordinativa.

Considerando o aspecto sintático da conjunção, o autor caracteriza-a como aquela que introduz uma oração inversível, ou seja, pode apresentar-se como principal ou como subordinada, sendo as exceções para a inversão, as conjunções consecutivas e as comparativas.

Macambira define que "A conjunção difere dos outros conectivos por ligar dois termos sintáticos idênticos" (p. 76), como dois predicados, dois complementos nominais, dois agentes da passiva, entre outros.

$O$ autor ainda considera que as conjunções podem fazer parte de dois tipos de estrutura: as essenciais e as acidentais. As primeiras são aquelas conjunções que têm exclusivamente esse papel, como e, mas, porém, ou. As segundas são as conjunções que pertencem também a outras classes de palavras, como os advérbios.

Evidencia-se no estudo de Macambira a preocupação pela descrição da estrutura da Língua Portuguesa, o que propiciou um leque de nomenclaturas e pouco aprofundamento lingüístico. Diferentemente de Said Ali e de Rocha Lima, Macambira apresenta uma descrição da estrutura da língua portuguesa, em lugar de mostrar as possibilidades de uso das construções concessivas.

Luft $\left(1987^{5}\right)$, em sua obra Moderna gramática brasileira, faz um esquema das orações concessivas, ampliando o que já havia sido enunciado em Rocha Lima (op.cit.), classificando em desenvolvidas (com conjunção ou locução conjuntiva e verbo no modo subjuntivo) e reduzidas de infinitivo, de gerúndio e de particípio. Ao classificar as orações concessivas como reduzidas de infinitivo, Luft agrega uma nova informação aos estudos das orações concessivas ao mostrar mais um tipo de combinação entre o conector concessivo e as formas nominais do verbo.

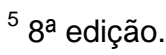


Os autores Cunha e Cintra $\left(1985^{6}\right)$ consideram que as orações subordinadas adverbiais concessivas são identificadas caso haja alguma conjunção subordinativa concessiva. Explicam que uma oração concessiva pode:

“a) vir intensificada em por mais que, por maior que, por melhor que, por menos que, por menor que, por pior que; ou mais que, maior que, melhor que, menos que, menor que, pior que, etc.

/Por mais que quisesse, / não conseguia decidir-se por nenhum.

(M. Torga, CM, 36.)

b) ficar reduzida à palavra que, com antecipação de predicativo:

/Padre que seja,/ se for vigário na roça, é preciso que monte a cavalo.

(Machado de Assis, OC, I, 735.)" (p. 590)

A respeito do item $b$, os autores ressalvam que há discussões entre lingüistas renomados (Sousa da Silveira, Martinz de Aguiar) que consideram que, nas orações concessivas, um pronome relativo em função predicativa.

Cunha e Cintra limitam-se a essa descrição básica das orações concessivas, sem outras considerações sobre seu uso e classificação, ainda porque não é o objetivo da obra que compuseram.

Bechara (2003) classifica as orações adverbiais concessivas em dois tipos: conectivas e justapostas. As concessivas conectivas são aquelas introduzidas por conectores como, ainda que, por mais... que, posto que.

Bechara, ao tratar das orações concessivas justapostas, define-as como sendo as que possuem o verbo no subjuntivo anteposto ao sujeito ou que sejam caracterizadas por determinadas expressões já citadas em Said Ali (1964). Nessa classificação de Bechara temos o que Said Ali (1964) mencionou sobre levar-se em consideração a proposição concessiva, denominando-a de "linguagem afetiva", que nada mais é do que se considerar o valor semântico da oração.

Esse conceito permite uma compreensão da concessão sem os elementos lingüísticos (conjunções) prototípicos. Bechara sugere que se leve em conta, como critério identificador de uma oração concessiva, não só o verbo

\footnotetext{
${ }^{6} 2^{\mathrm{a}}$ edição.
} 
no modo subjuntivo, mas a maneira de estruturação, o contexto e a entonação descendente do enunciado ${ }^{7}$.

Bechara também aponta um parentesco entre as orações concessivas e as orações condicionais, pois considera que estas podem encerrar idéias de concessão e, que muitas vezes, não existem demarcações rigorosas entre esses vários campos do pensamento.

Ao analisar Said Ali (1964), Rocha Lima (1982), Macambira (1978), Luft (1987), Cunha e Cintra (1985) e Bechara (2003), percebemos que as descrições convergem para as seguintes características sobre as orações concessivas:

i) a concessão é uma quebra de expectativa;

ii) é caracterizada pelo uso das conjunções subordinativas concessivas;

iii) aparece com verbos no modo subjuntivo;

iv) é possível a inversão de orações;

v) com comentários superficiais, reconhecem a proposição concessiva dissociada do modelo prototípico com conector;

vi) podem ser também reduzidas de infinitivo, particípio e gerúndio.

A perspectiva tradicional de descrição e normatização lingüística, perspectiva esta adequada ao propósito das obras mencionadas, mostram determinadas características que servem como um ponto de partida para se analisar a abordagem dos lingüistas sobre as construções concessivas e verificar as possíveis correspondências e, principalmente, os acréscimos propostos nas análises.

\footnotetext{
${ }^{7}$ A informação da entonação consta somente na $27^{a}$ edição da obra, não tendo sido mantida na $37^{a}$ edição e consta em nota de rodapé, a saber: "Não é o subjuntivo que de per si denota a concessão, mas a maneira de estruturação, o contexto e a entonação descendente. Devo esta observação ao sintaticista alemão Moritz Regula, em carta particular". In: Bechara, E. Moderna gramática portuguesa. 27. ed. São Paulo, Cia Editora Nacional, 1982, p. 231.
} 


\subsection{Abordagem dos lingüistas}

Os estudos de Mira Mateus et al. (1983) sugerem uma conceituação mais moderna das orações concessivas, uma vez que as autoras embasaram sua descrição em conceitos sugeridos por estudos de interação verbal, mecanismos lógicos (implicação, pressuposição), atos ilocutórios, implicaturas conversacionais, ao contrário do que ocorre nos manuais de gramática tradicional ${ }^{8}$.

Para o estudo da concessão, as autoras estabelecem alguns critérios de classificação desse tipo de construção gramatical, uma vez que consideram as particularidades, a semântica, a construção, como elementos importantes na construção das orações concessivas. Sendo assim, o evento concessivo prototípico é o da junção contrastiva (contrajunção), que pode ser classificada em factual, hipotética e contra-factual.

As construções contrastivas factuais caracterizam-se por sugerirem um contraste de valores ou de uma contra-expectativa, que pode ser representada pelo esquema $q$, conector $p$ ou conector $p$, $q$. Um exemplo para esse tipo de construção seria:

(2) $\quad \mid \mathrm{E}$ é quem assim procede que vem de | publico considerar menos humanitaria a | população da Bahia, sempre hospitaleira | e irresponsavel pelas <<loucuras do car- | naval. >> || Não, a hygiene ha de cumprir o seu | dever, embora surjam os advogados da | religião do interesse.

(Carta 82 - BA-Salvador/CL/Jornal de Noticias/1896)

A construção q (oração principal) e p (coração concessiva), no esquema $q$, conector $p$ nesta ocorrência (2) demonstram o contraste de valores mencionado pelas autoras, uma vez que o serviço sanitário da cidade executará suas atividades, enfrentando a "lei" representada pelos advogados, o que gera uma contra-expectativa e mostra que $p$ não é um argumento suficiente para a não-realização das tarefas da "hygiene".

\footnotetext{
${ }^{8}$ Vieira Lima (1987, p. 145), diz que "as autoras [Mira Mateus et al.] tentam dar uma guinada em direção a uma gramática que integre mecanismos de natureza lógico-semântica e pragmática no estudo das categorias morfo-sintáticas".
} 
Nas construções contrastivas hipotéticas, tem-se um acontecimento que não ocorreu, ou seja, que existe apenas como possibilidade. Segundo as autoras, são típicos dessa modalidade os conectores mesmo que e mesmo se:

(3) Tenho o trabalho de mudar as| letras, humas por outras; e depois de| mai afadigado grito: Viva Verney: Vi- | va o Bispo Azeredo! || Ora se tal he, e que não padece du-| vida: tambem hum tolo Camponez pó- | de trocar huma palavra Franceza por | huma Pórtugueza. Seja como for: co- | mo os jovens desejão, que o nosso Con- | gresso mude tudo, de huma só vez; | e mesmo que mudem os telhados para | baixo, e os alicerces para cima; Offe- | reço-lhe este Dialogo, e com elle o seu | coração. || O Camponez.

(Carta 2 - BA-Salvador/CL/Gazeta da Bahia/1830)

A ocorrência (3) confirma o que as autoras disseram sobre as expressões "mesmo que" e "mesmo se", pois em nosso trabalho todas as ocorrências têm valor hipotético. No exemplo acima, a possibilidade de algo nonsense como o proposto, existe apenas como possibilidade, não sendo responsável por nenhuma mudança argumentativa.

As construções contrastivas contrafactuais são caracterizadas pelo fato de exprimirem uma hipótese em que se nega um fato, isto é, uma hipótese que contraria um dado da realidade.

(4) Advertimos pela ultima vez aos nossos Correspondentes, que nem-uma correspondencia públicaremos sem que venhão assignadas, e reconhecidas; e ainda mesmo que assignadas e reconhecidas venhão, ficaraõ para um lado quando contenhão algum epitheto afrontoso, ou menos bem soante, seja em qualquer idioma antigo, ou moderno.

(Carta 426 - SP-São Paulo/CR/Farol Paulistano/1830)

Essa proposição em (4) exemplifica o que vem a ser uma construção contrastiva contrafactual, pois o fato de as correspondências chegarem com identificação na redação do jornal de nada vale se possuírem algum tipo de insulto.

Para cada item da classificação (factual, hipotética e contrafactual), as autoras propõem correlações entre tempos e modos verbais, de um lado, e conectores, do outro, dando a entender que os conectores selecionam a forma do verbo dos enunciados em que ocorrem.

No entanto, como são poucos os exemplos fornecidos pelas autoras, não é possível perceber a extensão dessas correlações no trabalho citado, 
apesar de havermos verificado a produtividade desse tipo de correlação em nosso trabalho.

Essa perspectiva de análise proposta por Mira Mateus et al. possibilita um diferente tratamento das construções concessivas e foi, inclusive, utilizado como parâmetro de análise em nosso trabalho.

Numa perspectiva funcionalista, Neves (1999 e 2000) e Rodrigues et al. (1999) investigam as relações concessivas, inicialmente, de maneira a separálas dentro da categoria das conexões contrastivas, como factuais/reais, contrafactuais/irreais e eventuais (hipotéticas).

Neves (2000) analisa as conjunções concessivas, classificando-as em factuais/reais, contrafactuais/irreais e eventuais e indicando quais as características de cada uma dessas subcategorias para as construções concessivas. A compilação dessa análise mostra que:

\section{a- Construções Factuais no presente:}

i) apresentam verbos no presente do indicativo na oração principal e verbo no presente do subjuntivo na oração concessiva;

ii) apresentam verbos no presente na oração principal e no futuro na oração concessiva;

iii) apresentam verbos no presente na oração concessiva e no passado télico na oração principal;

b- Construções Factuais no passado: apresentam predicações télicas ou não télicas na oração principal e no pretérito perfeito do subjuntivo (simples ou composto) na concessiva.

c- Construções Eventuais: apresentam o verbo no presente ou pretérito imperfeito (geralmente do subjuntivo) na oração concessiva e presente, futuro do presente e futuro do pretérito do indicativo na oração principal.

d- Construções Contrafactuais: são construções do passado ou do presente e apresentam verbos com pretérito imperfeito do subjuntivo na oração concessiva e pretérito imperfeito, futuro do pretérito ou presente do indicativo na oração principal.

Neves (1999) considera que uma análise é mais completa se se verificar o funcionamento da concessão em seus três domínios: o epistêmico (entidade 
lógica), o de conteúdo (semântico) e o conversacional (instrumento de um ato de fala).

A autora utiliza a proposta de Sweetser (1990), a mesma que tomamos por base teórica para nosso trabalho, para uma interpretação semântica das conjunções, que ampliaria as possibilidades de análise das ambigüidades pragmáticas nesses itens lexicais.

Sugere-se que as conjunções sejam interpretadas como: i) um veículo portador de conteúdo (domínio do conteúdo); ii) uma entidade lógica (domínio epistêmico); iii) um instrumento de um ato de fala (domínio dos atos de fala).

O Domínio do Conteúdo é caracterizado por relacionar fatos que são apresentados na oração concessiva como obstáculo, sendo estes fatos incapazes de impedir a realização dos eventos expressos na oração nuclear, causando assim uma frustração de expectativa, na qual q (nuclear) nega a inferência de $\mathbf{p}$ (concessiva).

(5) Cesse tudo, que a antiga Muza canta, \| Que outro louvor mais alto se levanta. || A POLICIA A' CACETE || Ainda que tenha hoje de occupar-me pouco do Arára: porque faz-se mister que me distraia um pouco com outros heróes, todavia naõ quero deixar de dizer alguma couza a seo respeito, á fim de que se naõ console deixando de ter seu quinhãozinho: assim pois vá policia á cacete.

(Carta 295 - PE-Recife/CR/O Aràra/1845)

$\mathrm{Na}$ ocorrência (5) temos um exemplo do domínio do conteúdo em evidência, em uma oração concessiva anteposta à oração nuclear e na sua proposição, a relação entre fatos e eventos fica evidente, uma vez que "não poder se ocupar dos assuntos da sociedade", seria fato suficiente para não fazê-lo, mas o redator faz a crítica à polícia local, mesmo não sendo o propósito do dia.

No Domínio Epistêmico, o que foi enunciado na oração nuclear contraria a conclusão a que se poderia chegar a partir da premissa dada pela concessiva. Verifica-se também que as concessivas antepostas $\mathbf{p}$ (concessiva) negam a inferência de $\mathbf{q}$ (nuclear).

(6) Senhor Redactor. - Não se póde ser auto- | ridade hoje em dia! Qualquer parvo | se julga apto para discutir todas as suas | medidas, embora avance proposições que, | proferidas na academia illustrada de São | Paulo, faria cahir por terra os bancos das | aulas. É o que acontece com o corres- | 
pondente que hontem estigmatisou a or- | dem do Senhor Cantinho, tendente a prohi- | bir o uso de assignalamentos na platéia.

(Carta 448 - SP-São Paulo/CL/Correio Paulistano/1854)

Em (6), a proposição expressa na oração concessiva nega o que se poderia analisar a partir da oração nuclear, ou seja, de que "qualquer ignaro discute as medidas tomadas pelas autoridades e se poderia supor que os que discutem não possuem nenhum conhecimento para debater com propriedade de causa".

No Domínio dos Atos de Fala, o falante faz uma auto-avaliação de inaptidão para o ato de fala declarativo da primeira oração, pois o falante inicia com um ato de fala declarativo para, logo a seguir, introduzir um outro ato de fala declarativo que desqualifica a afirmação categórica que fez.

(7) Eis, Senhor Redactor, quanto julgo do meu | dever declarar em abono da verdade, pro- | testando ao mesmo tempo não voltar a im- | prensa, ainda que alguem pretenda contra- | riar-me, pois que as pessoas que me conhe- | cem sabem que sou incapaz de faltar á ver- | dade. || Bahia 13 de março de 1869 || Anna Januaria de Souza Amaral.

(Carta 48 - BA-Salvador/CL/Jornal da Bahia/1869)

A ocorrência (7) é a única do nosso corpus que permite uma leitura no domínio dos atos de fala (conversacional), talvez por ser de origem "carta argumentativa", com a evidenciação do domínio dos atos de fala, na qual a leitora se manifesta para atestar a verdade dos fatos que narra, uma vez que é verdadeira e apóia-se na opinião das pessoas públicas para comprovar isso.

Um mesmo enunciado pode receber mais de uma interpretação, porém existem aqueles que são predominantes dependendo do tipo de construção sintática realizada. Segundo Neves (1999), das 55 construções concessivas por ela estudadas, a leitura epistêmica prevaleceu em 43 dos casos, enquanto a leitura do domínio do conteúdo contou com cinco casos e a leitura no domínio dos atos de fala ocorreu em sete dos casos. Tais resultados evidenciam que concessivas contrastam mais com conteúdos proposicionais, ou seja, negam conclusões possíveis a partir de premissas dadas.

São ainda apresentadas por Neves (1999), que se baseou nos estudos de Moeschler e Spengler (1981, apud Neves 1999, p. 558), duas possibilidades de uso da concessão: a lógica e a argumentativa. A concessão lógica é 
correspondente à leitura feita das conjunções no domínio do conteúdo, já a concessão argumentativa permite a diferenciação do argumentativismo forte e do argumentativismo fraco, além de possibilitar a análise entre duas conclusões implícitas e contrárias e seria o equivalente aos casos dos domínios epistêmicos e dos atos de fala já mencionados.

A representação da possibilidade argumentativa da concessão pode ser expressa com a seguinte fórmula:

$$
\begin{aligned}
& \mathbf{p} \Rightarrow \mathbf{r} \text { (a oração concessiva } \mathbf{p} \text { argumenta em favor da conclusão } \mathbf{r} \text { ) } \\
& \mathbf{q}=\sim \mathbf{r} \text { (a oração nuclear } \mathbf{q} \text { argumenta em favor de não-r) } \\
& \mathbf{q}=\text { argumento mais forte para } \sim \boldsymbol{r} \text { do que } \boldsymbol{p} \text { é para } \boldsymbol{r}
\end{aligned}
$$

(8) [...] He mui justo que sigamos | os costumes da nossa Santa Religiáo; | mas convém tambem que desappareção | excessos e luxos que accompanhão a al- | guns actos della. Estamos em o $19^{\circ} \mathrm{Se}$ - | culo, o Brasil caminha (ainda que á | passo(sic) lentos) á civilisação; he necessa- | rio assim elevar o nosso povo a admi- | rar e venerar a verdadeira essencia da | nossa Religião que consiste em huma mo- | ral pura encaminhando o homem á mais | subida perfeição; e não acostumal-o á | considerar como Religião aquelle que as | vezes tem sido causa della ter tido dis- | sidentes, e inimigos. [...] (Carta 13 - BA-Salvador/CL/Gazeta da Bahia, 1832)

$\mathrm{Na}$ ocorrência (8), temos a oração concessiva (p), que argumenta a favor de o Brasil desenvolver-se muito devagar (r). A oração nuclear (q) argumenta em favor de o Brasil chegar à civilização $(\sim r)$, o que não seria possível se o país continuasse atravancado (a passos lentos). Por fim, o argumento de $(p)$ não constitui razão suficiente para $(\sim r)$, resultando no fato de o Brasil, no fim, terminar por desenvolver-se e chegar à civilização.

A autora ainda tece considerações sobre a diferença entre o movimento concessivo no diálogo e o movimento concessivo no monólogo, os quais obedecem ao seguinte esquema:
a) Diálogo
L1 - faz uma proposição
L2 - discorda de L1
L1 - concorda com L2 e abandona a afirmação inicial 
b) Monólogo

L1 - distancia-se da própria proposição, de um ponto-de-vista dado pelo contexto e tem as características de uma retomada.

Podemos dizer que, no caso no monólogo, há uma polifonia na enunciação de L1, o que permite o distanciamento e a futura retomada do que estava sendo dito. As cartas de leitor e de redator analisadas mostram um movimento concessivo estabelecido no monólogo, pois mesmo sabendo da publicação do texto em um meio de comunicação pública, não existe interação real, o que permite a classificação das cartas como monólogos argumentativos.

A análise das formas do diálogo e do monólogo permite chegar à conclusão de que o pensamento concessivo possui duas etapas: i) elaboração de hipótese de objeção por parte do ouvinte; ii) refutação a essa objeção.

Quanto à posição da concessiva no complexo subordinativo no corpus analisado por Neves, $71 \%$ dos casos de concessão (39 ocorrências) apresentam a concessiva como posposta, 20\% (11 ocorrências) apresentam a concessiva anteposta e 9\% (cinco ocorrências) apresentam a concessiva intercalada na oração nuclear. Com esses dados, a autora infere que as orações concessivas pospostas não possuem função de tópico em todos os casos, mas sim de afterthought, já as orações concessivas antepostas topicalizam a concessão.

As considerações da autora sobre o afterthought ou reflexão a posteriori têm como base o funcionamento de operadores concessivos como um adendo em que o locutor retoma o que acabou de enunciar. Sobre o conector se bem que, Neves o considera como introdutor de um novo argumento, após o primeiro ter sido aparentemente concluído. Tal recurso só é possível pelo fato de o conector se bem que estar posposto: "A questão da posposição da oração concessiva pode ser relacionada com a própria natureza argumentativa da construção, em termos de interação" (p. 567).

Neves (1999) também faz uma série de observações sobre os dados das construções concessivas, nas quais prevalecem as seguintes características, quanto a: 
a) Predicação: $58,18 \%$ têm a oração concessiva de estado e a oração nuclear de estado, atividade, realização, mudança ou posição;

b) Relação modo-temporal: 40\% apresentam o verbo da oração nuclear no presente do indicativo e o da oração concessiva no presente do subjuntivo, presente do indicativo ou pretérito imperfeito do subjuntivo;

c) Modo Verbal: $58,18 \%$ das orações nucleares têm o verbo no modo indicativo e o da oração concessiva no modo subjuntivo;

d) Conectivo e Modo Verbal: 76,92\% são orações introduzidas por embora com oração nuclear no indicativo e oração subordinada no subjuntivo e $10 \%$ para se bem que com oração nuclear no indicativo e oração subordinada no indicativo;

e) Posição predominante da Oração Concessiva e do Conectivo: mesmo que (anteposta), ainda que (posposta), embora (posposta), apesar que (posposta), apesar de que (posposta), se bem que (posposta), por mais que (anteposta);

f) Posição da Oração Concessiva e Jogo de Polaridade: $64,10 \%$ dos casos com oração nuclear afirmativa e a oração concessiva afirmativa, na posição posposta;

g) Conectivo e ordem das orações nas construções factuais e eventuais: $67,27 \%$ das ocorrências são em construções factuais na posição posposta;

h) Relação Modo-temporal nas concessivas factuais: $60,42 \%$ de construções factuais com oração nuclear com presente do indicativo e oração concessiva com presente do subjuntivo, presente do indicativo ou pretérito imperfeito do subjuntivo.

Tais informações sobre as construções concessivas permitiram à autora chegar às seguintes conclusões:

- A natureza lógico-semântica das construções concessivas a aproxima das construções causais e das condicionais, inclusive por conta do jogo de polaridade dessas construções; 
Em uma construção concessiva, portanto, a causalidade pressuposta na oração concessiva (p) é negada na oração nuclear (q); e a condição pressuposta em (p), por sua vez, não é suficiente para evitar q, ou seja, para evitar o cumprimento de q. (p. 587).

- A natureza argumentativa das construções concessivas a aproxima das construções adversativas, classificando-se assim uma categoria mista concessiva-argumentativa. Essa natureza é a que explica o fato de um maior número de ocorrências entre oposição de pensamentos (no domínio epistêmico) e entre atos de fala, assim como a baixa freqüência no domínio do conteúdo;

- A ambigüidade de análise das conjunções nos domínios do conteúdo, epistêmico e dos atos de fala nem sempre se resolve no contexto pragmático, sendo possível, em alguns casos, uma dupla leitura da construção concessiva, ou seja, em dois domínios diferentes;

- A posição da oração concessiva permite a organização da informação em tópico (se as orações concessivas estiverem antepostas), afterthought (caso a posição seja posposta) e topicalização de elementos da oração nuclear (em orações concessivas intercaladas);

- A subcategorização em factuais, eventuais e contrafactuais relaciona-se ao conectivo concessivo utilizado. O tipo de conectivo utilizado também favorece o emprego do modo verbal no indicativo ou no subjuntivo.

A profundidade dos estudos de Neves (1999), assim como a variedade de contribuições de teorias lingüísticas para a análise das construções concessivas, permitiu um avanço na perspectiva de pesquisa da concessão.

Neves (2000) produz um estudo que visa, de maneira didática, montar um panorama de análise das construções concessivas. Para isso, divide seu estudo em: i) modo de construção; ii) as relações expressas; iii) a ordem nas construções, e; iv) os subtipos das construções concessivas.

Quanto ao modo de construção, a autora utiliza a forma canônica de concessivas com conectores que é embora $p, q$ e faz a observação de que as 
conjunções concessivas podem ser simples (como embora e conquanto) ou compostas, também chamadas de locuções conjuntivas (como mesmo que, ainda que, posto que, apesar (de) que, se bem que, por mais que, por muito que, por menos que, nem que, ainda quando, não obstante).

Ao desenvolver os estudos sobre as relações expressas nas conjunções concessivas, Neves (2000) retoma as considerações presentes na publicação anterior (Neves, 1999) que se pautam na análise das construções concessivas a partir da:

a) diferenciação/semelhanças destas com as construções causais e condicionais;

b) divisão das construções concessivas em factuais/reais, constrafactuais/irreais e eventuais;

c) análise lógico-semântica dos domínios epistêmico, do conteúdo e dos atos de fala;

d) natureza argumentativa: argumentativismo forte e fraco, assim como polaridade positiva ou negativa.

A retomada das categorias de análise estabelecidas pela autora em estudo anterior tem como objetivo desenvolver alguns conceitos e tópicos que haviam sido somente iniciados em Neves (1999).

Neves (2000) utiliza a nomenclatura prótase e apódase para referir-se à oração concessiva com conector e à oração principal, respectivamente. $\mathrm{O}$ elemento que estabelece uma disjunção na construção concessiva é aquele com carga de negação (como um advérbio de negação, por exemplo) e que numa construção pode ter uma função positiva ou negativa, o que depende somente de apresentar-se na prótase ou na apódase.

Ao analisar a ordem das construções concessivas, Neves (2000) também amplia a caracterização dos elementos da ordem nesse tipo de construção, o que resulta nas seguintes observações, caso sejam:

a- pospostas: há uma asserção nuclear e uma posterior objeção;

b- antepostas: primeiro a objeção é efetuada, para posterior asseveração; 
c- antepostas com posição tópica: evidenciam/topicalizam a informação mais conhecida pelo interlocutor;

d- pospostas com função de tópico discursivo: há uma reflexão a posteriori;

e- posposição com função interacional: composição da concessão pelos interlocutores;

f- focalização de elementos da oração principal: destaca adjetivos e complemento verbal, entre outros;

g- posposta ao sujeito da oração principal: acentua o caráter tópico do sujeito.

Os estudos de Neves (1999 e 2000) contribuíram para uma abertura de análise do complexo concessivo com a perspectiva de teorias que envolvem a semântica, a sintaxe e a pragmática, o que se mostra mais eficaz para dar conta desse fenômeno lingüístico, assim como associar diferentes áreas da pesquisa lingüística que interagem quando da língua em uso.

Alguns dos pontos analisados por Neves, como os domínios de leitura, o tipo de concessão, a correlação modo-temporal, serão utilizados em nosso trabalho como critérios de análise, sendo que para alguns itens buscaram-se mais explicações ou aprofundamento.

Os estudos de Rodrigues et al. (1999) permitiram um maior conhecimento, por exemplo, da correlação modo-temporal nos complexos concessivos, o que contribuiu para a análise dos dados deste trabalho.

Os autores desenvolvem uma pesquisa cujo objetivo é investigar as relações entre a correlação ou concordância de tempos e modos verbais nas orações, a partir de duas hipóteses: i) da existência de correlação entre o valor e o esquema modo-temporal das construções concessivas; ii) da correlação entre jogo modo-temporal e conector utilizado na construção concessiva, sendo também as hipóteses adotadas para nosso trabalho.

Os estudos de Mira Mateus et al. (1983) evidenciam nesse quesito uma preocupação com a correlação modo-temporal, visto que a considera responsável pela coesão temporal no texto. Essa questão já era preocupação dos gramáticos latinos, segundo Ernout e Thomas (1959, apud Rodrigues et al., 1999, p. 654), pois estes já percebiam haver relação entre proposições das 
subordinadas com a oração principal, inclusive definindo que o modo subjuntivo seria o modo com maior possibilidade de jogo modo-temporal.

Baseados nessa hipótese e apoiados em teorias mais recentes, Rodrigues et. al. adotam a perspectiva da concordância de tempos. Segundo Weinrich (1968, apud Rodrigues, 1999, p. 654), os tempos verbais podem ser separados em dois grupos: i) tempos do mundo comentado e ii) tempos do mundo narrado.

No primeiro grupo, do mundo comentado, os tempos verbais são os seguintes: presente, presente contínuo, futuro do presente simples e composto do indicativo. O segundo grupo, do mundo narrado, é composto por: pretéritos perfeito, imperfeito, mais-que-perfeito e futuro do pretérito do indicativo.

Os autores tomam como base os estudos de Weinrich para explicar, por exemplo, o fato de, em português, o pretérito perfeito pertencer tanto ao mundo comentado quanto ao mundo narrado.

Rodrigues et al. (1999) também apresentam a concessão como uma não-satisfação de uma condição necessária, não-satisfação esta que se estabelece a partir do conector concessivo, o qual funciona como um elo entre o conteúdo proposicional de um dos membros do complexo concessivo ao outro, mantendo assim uma unidade semântica. Além disso, estabelecem a divisão das proposições em factuais, hipotéticas e contrafactuais, como Mira Mateus et al. (1983) e Neves (1999 e 2000).

As construções factuais unem duas proposições ou "enunciados que são apresentados pelo falante como reais ou verdadeiros" (p. 657). Para o caso de se bem que, os autores constatam que as ocorrências encontradas podem ser, todas, classificadas como factuais - predominantemente com formas no modo indicativo. Os autores comentam que o conector utilizado é que introduz a diferença dos modos verbais.

Com a análise dos dados, Rodrigues et al. (1999) descrevem as construções concessivas com o modo indicativo na oração núcleo e modo subjuntivo na oração concessiva. Nos casos em que figura o indicativo na subordinada concessiva, é possível considerar dois fenômenos: essas orações apresentam um estatuto sintático-semântico diversificado e possuem valores ou funções de argumentação especial. 
Um exemplo de análise efetuada pelos autores seria a da locução conjuntiva se bem que, que possui modo verbal do indicativo tanto na oração principal, quanto na concessiva. Acrescentando que:

Em termos lógico-semânticos, se bem que não introduz oração concessiva prototípica. Neste caso, há que se definir o estatuto sintático desta conjunção (p. 667).

Os autores fazem esse comentário por não considerarem o conector se bem que como tipicamente concessivo, pois, na análise dos exemplos apresentados, consideram-no como um introdutor de uma digressão, por estabelecer uma relação de contrajunção com um conteúdo pressuposto.

A ordem da oração concessiva pode ser invertida, ou seja, tanto o esquema conector $\mathbf{p}$, $\mathbf{q}$ como o esquema $\mathbf{q}$, conector $\mathbf{p}$ podem ser aceitos, sem prejuízo semântico para as proposições.

Os autores ainda comentam que os conectores se bem que, apesar que, apesar de que são considerados como "pseudo-concessivos", por não apresentarem características das orações concessivas tradicionais.

Por fim, os autores confirmam as hipóteses levantadas para o início do trabalho e evidenciam questões pertinentes que devem ser consideradas, a saber:

1. "As regras de correlação modal seriam impostas pelo complexo sintático enquanto as de correlação temporal seriam exigência do texto" (p. 671);

2. Alteração semântica, nos casos em que há uma substituição do modo indicativo para o subjuntivo;

3. A possibilidade de intercâmbio de formas do indicativo e do subjuntivo para outras orações subordinadas, como ocorre com as condicionais hipotéticas.

As construções concessivas, muitas vezes, podem adquirir um caráter híbrido, pelo parentesco com as construções adversativas, causais e condicionais. No trabalho de Bechara (2003) esse parentesco é apontado como um item lingüístico a ser analisado e salienta a importância do espaço para 
reflexão sobre o uso lingüístico que, muitas vezes, é suplantando pela necessidade de divulgação da NGB (Nomenclatura Gramatical Brasileira) e da norma do padrão culto.

Esse espaço para reflexão sobre as relações das construções concessivas com outros tipos configurou-se no trabalho de Neves (1999), no qual existe a discussão "O que é uma construção concessiva?", que retoma os conceitos normativos e amplia essas caracterizações iniciais, associando as construções concessivas às construções adversativas, ressaltando que as primeiras aparecem em orações subordinadas e as segundas em orações coordenadas.

Essa associação entre as construções concessivas e as adversativas, por exemplo, já havia sido feita por Mira Mateus et al. (1983), que consideram o item mas como pertencendo à classe das adversativas, não podendo sofrer, portanto, as mesmas inversões da ordem das proposições que compõem as construções concessivas, sem alteração do conteúdo semântico das proposições.

Neves (1999) apresenta considerações sobre a concessão e sobre a constituição do complexo concessivo que, em princípio, é composto de uma oração principal e de uma oração subordinada concessiva. Semanticamente semelhantes às concessivas, as construções adversativas são sintaticamente marcadas pela coordenação. A diferença entre adversativas e concessivas se dá pelo fato de as concessivas efetuarem uma quebra de expectativa, o que não ocorre com as adversativas.

A resolução da relação entre adversativas e concessivas não é simples, como não é simples a implicação que se pode apontar entre relações causais, condicionais e concessivas, todas elas expressivas de uma conexão "causal" lato sensu entendida, e todas elas explicáveis em dependência da satisfação/ nãosatisfação de necessidade/ de suficiência de determinadas condições. (Neves 1999, p. 545)

É destacada, também, em Neves (1999) a relação entre as construções condicionais e as construções concessivas, por expressarem uma conexão "causal" que pode ser explicada pela dependência de satisfação/não-satisfação de determinadas condições. 
A autora ainda atribui um grande parentesco entre causais, condicionais e concessivas, que se caracterizam, respectivamente, pela dependência de satisfação, não-satisfação ou suficiência de certas condições, formando um continuum semântico entre si.

Sob esse aspecto da relação causa/conseqüência, pode-se dizer que, nas construções concessivas, uma causa (ou uma condição) é expressa na oração concessiva, mas aquilo que dela se pode esperar é negado na oração nuclear. (p. 547)

As construções concessivas, se analisadas a partir de um esquema lógico-semântico, são construções nas quais a oração concessiva (p) não constitui razão suficiente para contrariar a proposição da oração principal (q) ou no esquema lógico semântico ( $p$ não-q), sendo tal proposta a mesma já vista em Mira Mateus et al. (1983).

Neves $(1999,2000)$ analisa o parentesco entre construções concessivas e condicionais, sob uma perspectiva lógico-semântica, a partir dos estudos de Lopes (op. cit. p., 549-550) para explicar tal parentesco:

\begin{abstract}
Uma oração nuclear afirmativa em uma construção concessiva será, na condicional contraditória, uma negativa, e que uma oração nuclear negativa em uma construção concessiva será uma oração afirmativa na construção condicional. [...] todo o jogo das relações entre construções contrastivas (isto é, concessivas ou adversativas) por um lado, e construções condicionais correlacionadas, por outro lado, envolve sempre a intervenção de pelo menos uma negação.
\end{abstract}

A principal característica que diferencia as construções condicionais das construções concessivas relaciona-se com a escolha dos elementos disjuntos. Nas condicionais, a escolha dos elementos disjuntos na oração principal determina o resultado na subordinada, enquanto "o que se verifica na construção concessiva é que a escolha de qualquer um dos elementos disjuntos não influi no conteúdo da oração principal, pois é incapaz de alterá-lo" (p. 871).

Nas construções condicionais a escolha disjuntiva determina o resultado da apódose (se $p, q /$ se não $p$, não $q$ ), já nas construções concessivas, o 
resultado da oração principal (classificada como $q$ ou apódose) é independente da escolha que se faça de qualquer dos elementos disjuntos.

Ainda com relação ao parentesco entre concessivas, condicionais e causais, Neves comenta que, nas causais, há um vínculo causal afirmado; nas condicionais, o vínculo causal é hipotetizado e, nas concessivas, o vínculo causal é negado. Tal diferenciação abre espaço para compreender o funcionamento das construções condicionais com matiz concessivo, como no caso de mesmo se, que contém semanticamente uma condição que, realizada, não é suficiente para garantir a realização do conteúdo dado por uma inferência "natural" - o que, aliás, é característica da concessão: introduzir um argumento que segue um caminho contrário ao esperado.

Com todas essas informações sobre as construções concessivas, provenientes da análise das gramáticas tradicionais e dos estudos de lingüistas efetuados mais recentemente, observamos que esta análise deverá pautar-se nos estudos mencionados, com o objetivo de verificar se o funcionamento das construções concessivas nas cartas argumentativas do século XIX possuem as mesmas características encontradas.

Orientando-nos, principalmente, pelas análises dos trabalhos de Neves (1999 e 2000) e Rodrigues et al. (1999), para definição dos fatores de interpretação dos complexos concessivos, com o objetivo é verificar se os complexos concessivos da língua oral (corpus utilizado pelos autores mencionados) e os complexos concessivos da língua escrita (corpus de cartas argumentativas utilizado neste trabalho), possuem as mesmas características, visto serem de modalidades, de períodos históricos e de objetivos diferentes, para uma contribuição aos estudos da história do Português Brasileiro. 


\section{3. $O$ corpus sob análise}

\subsection{Justificativa e origem}

O material escolhido para a análise lingüística faz parte do corpus do "Projeto Para a História do Português Brasileiro" (PHPB), coordenado pelo Profo $^{\circ}$. Dr ${ }^{\circ}$. Ataliba T. Castilho, e tem como objetivo estudar o processo de formação do Português do Brasil. Uma das tarefas dos pesquisadores desse projeto é a formação de um corpus representativo de textos de diversos tipos e gêneros, com a finalidade de reunir uma ampla variedade de material lingüístico para estudo da história do português brasileiro.

Utilizamos a publicação de Barbosa e Lopes (2004) composta de cartas de redatores e de editores de 114 jornais oitocentistas de seis estados brasileiros: São Paulo, Rio de Janeiro, Bahia, Minas Gerais, Pernambuco e Paraná. As cartas coletadas foram separadas por períodos: fase 1 (18081840), fase 2 (1841-1870) e fase 3 (1871-1900) ${ }^{9}$.

As 566 cartas selecionadas têm como data-ícone o início da imprensa no Brasil (1808) e o agrupamento dessa documentação em fases mostra a divisão geracional de 30 anos utilizada geralmente na divisão de corpora orais. Para edição dessa documentação, foram mantidas a ortografia e a pontuação originais, assim como respeitadas notações originais do jornal.

O pronunciamento dos leitores brasileiros que se deparavam com um novo meio de socialização de informações e canal de reivindicação, esclarecimento ou opinião, assim como os redatores de jornais impressos que eram (e ainda são) formadores de opinião pública, permitem a verificação das estratégias argumentativas utilizadas para essa novidade dos primórdios do século XIX: a possibilidade das discussões privadas serem veiculadas num meio público, mostrando inclusive a história da imprensa no Brasil.

Considerando-se não só o evento político-social que a imprensa livre no Brasil concretizou no início do século XIX, mas também o uso do vernáculo escrito pela população letrada na época, enxergamos nessa escolha de corpus

\footnotetext{
${ }^{9}$ As cartas com construções concessivas utilizadas para análise foram: 2, 13, 15, 18, 22, 26, 31, 42, 48, 57, 62, 67, 74, 82, 89, 109, 115, 116, 149, 174, 208, 223, 261, 266, 273, 277, 278, 279, 288, 290, 312, $316,320,326,329,348,353,354,361,365,375,376,377,385,386,387,391,408,426,448,451,482$, $498,513,532$ e 553.
} 
a oportunidade de verificar como a construção complexa concessiva foi utilizada publicamente nos meios escritos formais.

Esta análise diacrônica (se considerarmos que os dados do corpus abrangem um século que foi dividido em três períodos) ainda permitirá uma comparação com o uso atual das construções concessivas e dos estudos já efetuados sobre essa temática.

\subsection{As cartas e os graus de formalidade}

A fim de traçar uma trajetória do estudo dos gêneros, Bakhtin (1997: 279) considera que "todas as esferas da atividade humana, por mais variadas que sejam, estão sempre relacionadas com a utilização da língua", o que demonstra que as mais variadas formas de utilização da língua distinguem-se e completam-se sem perder a unidade nacional de uma língua, hipótese esta verificada na análise das cartas jornalísticas oriundas de várias cidades brasileiras.

Os gêneros discursivos orais ou escritos constituem-se não só pelo conteúdo temático ou pelos recursos da língua, como a composição lexical, da frase ou da sintaxe, mas também pelo seu conteúdo composicional que considera o interlocutor como possuidor de uma atitude responsiva ativa ao que o locutor/escritor estabelece na comunicação.

Ignorar a natureza do enunciado e as particularidades de gênero que assinalam a variedade do discurso em qualquer área do estudo lingüístico leva ao formalismo e à abstração, desvirtua a historicidade do estudo, enfraquece o vínculo existente entre a língua e a vida. (Bakhtin, 1997, p. 282).

Segundo Bakhtin, os gêneros do discurso podem ser divididos em dois tipos: os gêneros primários (mais simples, como a carta) e os gêneros secundários (mais complexos, como o romance, o teatro e o discurso científico). Os gêneros secundários absorvem e transmutam os gêneros primários, tornando-os componentes dos gêneros secundários. 
A língua escrita corresponde ao conjunto dinâmico e complexo constituído pelos estilos da língua, cujo peso respectivo e a correlação, dentro do sistema da língua escrita, se encontram num estado de contínua mudança. (Bakhtin, 1997, p. 285).

Com base nesse pressuposto de Bakhtin e do tipo de texto selecionado para análise de ocorrências das construções do complexo subordinativo concessivo, consideramos as cartas como possuidoras de um perfil específico na produção escrita.

De uma perspectiva didática e pedagógica, temos os estudos de Kaufman e Rodríguez (1995), que consideram que os textos, em geral, são constituídos por mais de uma das funções da linguagem já estabelecidas por Jakobson $^{10}$ (informativa, literária, apelativa e expressiva) e classificá-los somente de acordo com a função predominante seria restringir as variedades do uso social da escrita.

A classificação proposta, então, é de uma intersecção entre a trama predominante (descritivo, argumentativa, narrativa e conversacional), e a função (informativa, expressiva, literária e apelativa) de cada texto. O material do PHPB por nós analisado corresponde a textos que podem ser classificados como carta com função apelativa, em uma trama argumentativa.

Baseando-se nessas características foi possível detectar que nas cartas de redatores e de leitores do século XIX da imprensa brasileira, a função argumentativa aparece justamente com o objetivo de dissuadir o leitor de que houve uma injustiça que está sendo justificada ou, então, que existe um posicionamento qualquer do redator sobre um determinado assunto ou acontecimento, sendo que em ambos os casos, o leitor do jornal é induzido a compreender, aceitar e apoiar o emissor da carta (redator ou leitor do jornal).

Oesterreicher (2000) explica que os textos possuem graus de formalidade e de informalidade, dependendo das situações de uso, que se distribuem entre dois extremos de um contínuo comunicativo, entre a língua oral e a língua escrita.

Esse contínuo comunicativo mencionado pelo autor pode ser definido a partir de pesquisas pragmáticas, sociolingüísticas e psicolingüísticas que

\footnotetext{
10 Jakobson, R. Ensayos de lingüística general. Barcelona, Editorial Ariel, S.A., Colección Letras e Ideas,
} 1984. 
seriam suficientes para caracterizar os parâmetros para o comportamento comunicativo dos interlocutores, dependendo da situação e do contexto.

Considerando-se que existe diferença no grau de formalidade da comunicação entre os interlocutores da língua falada para da língua escrita, Oesterreicher (2000, p. 4) propõe os seguintes parâmetros para aferição de graus de formalidade do discurso ${ }^{11}$ :

\begin{tabular}{|l|l|r|r|}
\hline \multicolumn{1}{|c|}{ Língua Falada } & \multicolumn{1}{|c|}{ Língua Escrita } \\
\hline (1) & Comunicação privada & Comunicação pública & ( \\
\hline (2) & Interlocutor íntimo & Interlocutor desconhecido & 2 \\
\hline (3) & Participação emocional forte & Participação emocional fraca & $\mathbf{3}$ \\
\hline (4) & Ligação situacional e de ação & Desligamento situacional e de ação & $\mathbf{4}$ \\
\hline (5) & Ligação referencial na situação & Desligamento referencial da & $\mathbf{5}$ \\
\hline (6) & Presença espaço-temporal & situação & \\
\hline (7) & $\begin{array}{l}\text { Cooperação comunicativa } \\
\text { intensa }\end{array}$ & Distância espaço-temporal & $\mathbf{6}$ \\
\hline (8) & Diálogo & Cooperação comunicativa mínima & $\mathbf{8}$ \\
\hline (9) & Comunicação espontânea & Monólogo & $\mathbf{8}$ \\
\hline (1) & Liberdade temática & Tema fixo & $\mathbf{0}$ \\
\hline
\end{tabular}

A combinação dos valores (1), (2), (3)... (10) define um extremo conceitual que pode ser chamado de imediatez comunicativa, ao passo que a combinação (1, 2, 3... (1) corresponde ao que se pode classificar como distância comunicativa. O caráter de escala estabelecido pela oposição imediatez comunicativa e distância comunicativa deve-se, primeiramente, à gradação interna dos parâmetros e, em segundo lugar, à combinação desses valores paramétricos.

Para aplicar esses conceitos, Oesterreicher coloca como exemplo a situação comunicativa de entrevista de emprego, na qual existe uma

\footnotetext{
${ }^{11}$ As tabelas foram traduzidas e adaptadas de Oesterreicher (2000, p. 4).
} 
combinação dos parâmetros formais (típica da linguagem escrita) e informais (língua falada).

Nesse caso, há uma mistura dos parâmetros, pois se considera a situação da comunicação. Os parâmetros $\mathbf{2}, \mathbf{3}, \mathbf{4}, \mathbf{6}$ que estão normalmente relacionados à língua escrita pelo grau de formalidade, aparecem na situação de entrevista de emprego que, apesar de ser uma comunicação falada, exige um maior grau de formalidade.

Os parâmetros (6) e (8) são os únicos prototípicos da língua falada dessa situação, ficando os parâmetros (1), (7), (9) e (1) numa escala mais aproximada dos parâmetros de formalidade. Graficamente, poder-se-ia representar a entrevista de emprego da seguinte maneira:

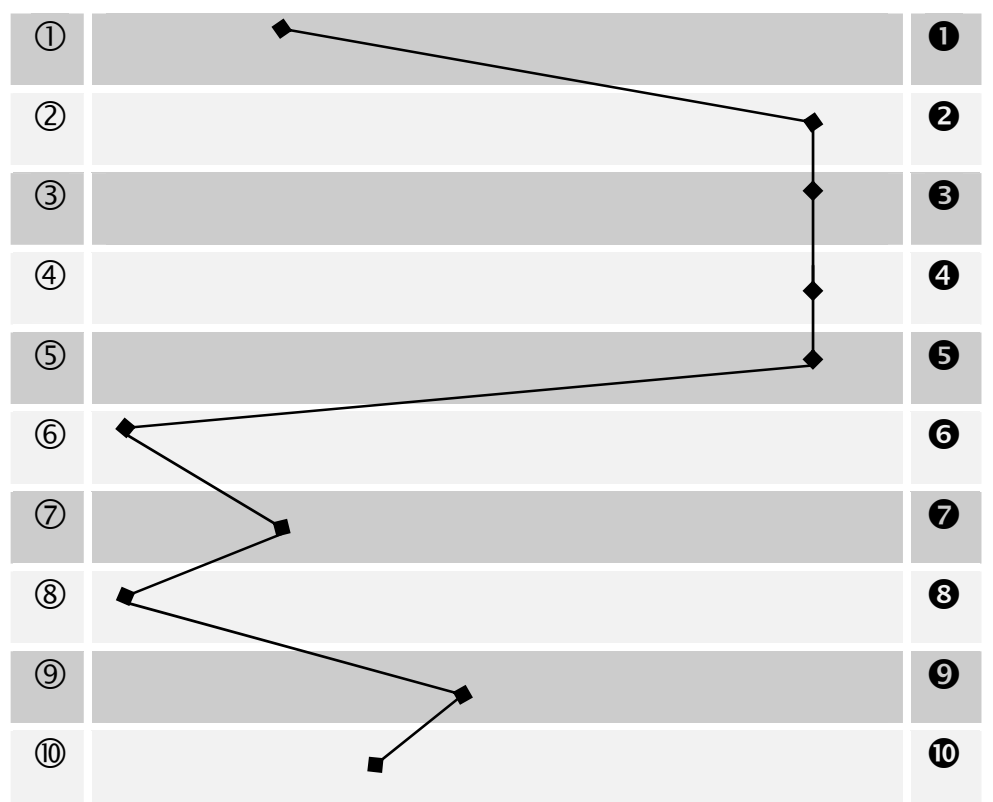

Oesterreicher considera a possibilidade de uma gradação na escala de formalidade, assim como uma análise de acordo com a situação comunicativa.

Tais perspectivas permitiram uma análise que está representada no gráfico que segue: 


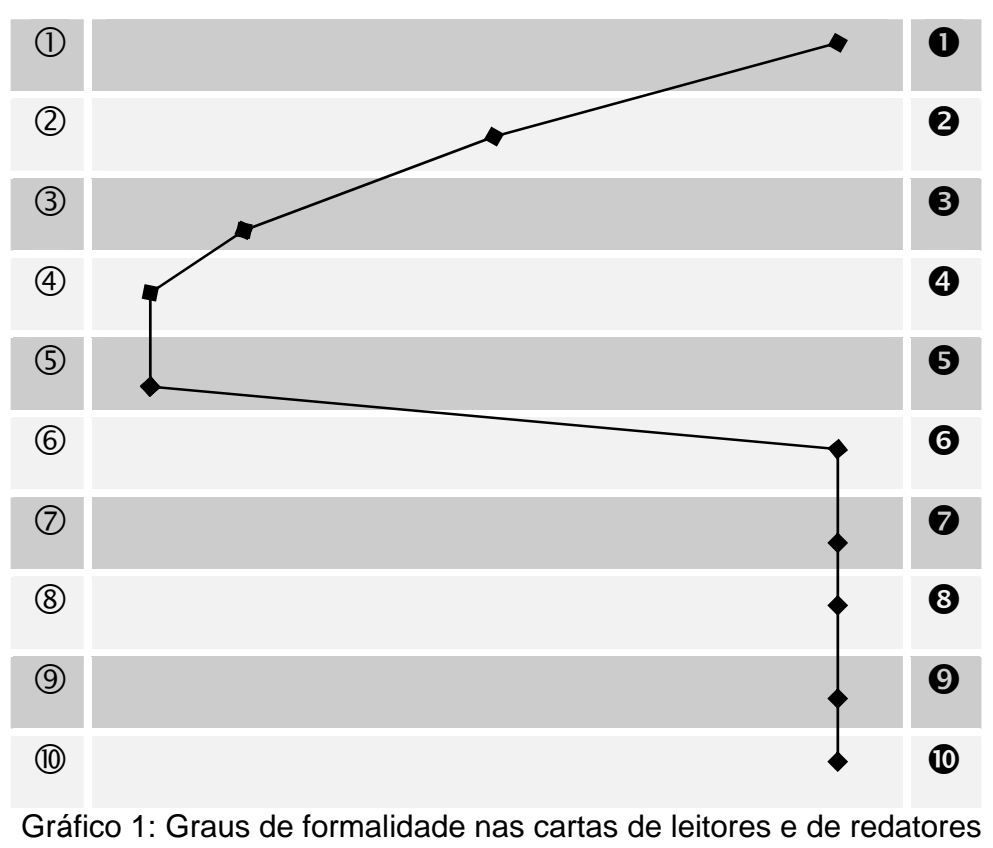

No gráfico (1) considerou-se que os parâmetros $\boldsymbol{0}, \boldsymbol{\sigma}, \boldsymbol{\theta}, \boldsymbol{8}, \boldsymbol{\theta}$ e (1), que são típicos da língua escrita, não sofreram alteração no uso das cartas de leitores e de redatores, já os parâmetros (4) e (5) que são típicos da língua falada, encaixam-se na categoria das cartas, uma vez que os leitores e redatores possuem tanto uma relação com a situação e a ação expressa nas cartas, como também uma referência explícita à situação comentada.

A interação com o interlocutor íntimo (2) ou desconhecido (2), obedece ao critério utilizado para a língua falada ou língua escrita respectivamente, é o parâmetro que classificamos como intermediário na escala de formalidade e de informalidade, visto que o interlocutor não responde à interlocução imediatamente.

No entanto, o pronunciamento no jornal tem por objetivo um posicionamento por parte do leitor ou redator para alguma pendência pessoal ou ideológica, fator esse que ligaria o parâmetro (3) muito mais à língua falada do que à escrita, devido à participação emocional do produtor do texto.

Esse pronunciamento no jornal também servia para comentários sobre a política e a sociedade da época, o que pressupõe ser o interlocutor nem desconhecido, nem íntimo, por isso a classificação intermediária no gráfico dos graus de formalidade e a classificação do parâmetro (4) (ligação emocional) também estar mais próximo da língua falada, uma fez que as cartas não são escritas sem se considerar a situação de interlocução. 
Com essa classificação dos parâmetros nas cartas, é possível compreender o porquê desse tipo de texto, muitas vezes, demonstrar um caráter híbrido quanto ao grau de formalidade.

A combinação dos elementos mais formais com os menos formais, dependendo da situação de comunicação, esclarece fatores como o grau de envolvimento do leitor ou redator das cartas analisadas, com a situação debatida, o que diferencia essa categoria de texto das demais categorias de textos argumentativos da língua escrita.

\subsection{Gênero textual e intenção discursiva}

Para elaboração deste trabalho, pensou-se, inicialmente, em efetuar um panorama das construções concessivas levando-se em consideração dois tipos de modalidade (falada e escrita), dois períodos de tempo (século XIX e XX), assim como a variedade do tipo de usuário (com escolaridade e sem escolaridade).

Após a análise de inquéritos da língua falada e do levantamento das ocorrências concessivas nesse corpus, confirmamos a impressão inicial que tínhamos sobre a escassez dessas ocorrências em situações de informalidade, com falantes de pouca escolaridade e na modalidade falada, impressão esta também demonstrada por Neves (2002, p. 148):

Outra observação interessante diz respeito ao fato de que, na língua falada, a freqüência de concessivas é bastante baixa, em relação às demais relações aparentadas (causais propriamente ditas e condicionais). [...] Na língua escrita, sabese que a ocorrência de concessivas é um pouco maior, mas muito menos significativa do que a das outras relações referidas.

Mesmo confirmando a hipótese inicial de que haveria um número muito reduzido de construções concessivas em corpus da língua falada, não havia um suporte teórico que explicasse esse fenômeno, até que fizemos a leitura de Decat (1995) sobre a incidência de construção de relações adverbiais 
dependendo do gênero do discurso, da modalidade e da variação individual do falante.

A pesquisa efetuada pela autora utilizou dez informantes com escolaridade superior, faixa etária entre 30 e 45 anos, tendo como produto textos de natureza narrativa (oral e escrita) e textos de natureza dissertativa (oral e escrita).

Os aspectos analisados a partir desse material foram: i) a incidência de construções adverbiais; ii) tipo de relação adverbial em cada gênero; iii) a posição e a forma das cláusulas adverbiais, aliadas à função textual-discursiva.

A autora salienta que há uma predominância do tipo de relação em cada gênero do discurso, tendo então discursos com predominância narrativa e discursos com predominânica argumentativa. Para os primeiros, os tipos de relações constituem elementos de orientação e de avaliação; para os segundos, de encaminhamento e argumentação.

Embora em gêneros diferentes, há uma correspondência que estabelece a função a que se prestam as relações adverbiais, ou seja, a orientação (na narrativa) e o encaminhamento (na dissertação) propiciam o uso das relações de tempo e de propósito; já a avaliação (na narrativa) e a argumentação (na dissertação), permitem o uso de relações de motivo, de condição, de concessão, de modo e de exclusão.

Os resultados das análises demonstraram uma gradação nas incidências de construções adverbiais, sendo esta: Narrativo oral $\rightarrow$ Dissertativo oral $\rightarrow$ Dissertativo escrito $\rightarrow$ Narrativo escrito.

De acordo com os resultados, ainda é possível verificar que o gênero é o fator que determina a incidência de relações adverbiais, mesmo considerando que os demais fatores, como modalidade e variação individual também influenciem na articulação hipotática das cláusulas.

O gênero do discurso, em função dos propósitos e objetivos a serem alcançados pelo ato comunicativo, determina (ou favorece) o surgimento de certos tipos de relações. [...] 0 gênero apresenta-se com maior peso nessa tarefa de determinar a forma do discurso. (Decat, 1995, p. 24)

A autora analisou 490 ocorrências de relações adverbiais, sendo elas divididas em: tempo, propósito, motivo, condição, concessão, modo e exclusão. 
Do total dessas ocorrências, para as relações concessivas, tem-se para o gênero narrativo 11 ocorrências (seis no oral e cinco no escrito) e para o gênero dissertativo 20 ocorrências (seis no oral e 14 no escrito), o que representa somente $6,3 \%$ do total de incidência de todas as relações adverbiais.

Com relação às construções adverbiais concessivas, a autora tece algumas considerações sobre a preferência de uso da concessão (gênero dissertativo) e na modalidade na qual é encontrada com maior freqüência (escrita).

O comportamento do discurso dissertativo, em especial o escrito, no que se refere à relação de concessão, explica-se uma vez mais pela natureza dessa relação. Fazendo parte do campo semântico de uma relação mais abrangente [...] a proposição relacional de concessão está, por isso, vinculada, por um lado, a assuntos textuais de apresentação e explicação, característicos do gênero dissertativo, e, por outro, à elaboração característica da escrita. (Decat, 1995, p. 25)

Outros fatores também foram mencionados com relação à concessão, como o fato de apresentar-se como satélite (na relação núcleo-satélite) e fundo (que dá suporte à linha principal de eventos), não havendo uma explicação para a anteposição das orações nas construções concessivas.

Ainda para a concessão, a autora considera duas outras teorias, a de que a função avaliativa presente na concessão poder-se-ia apresentar em todo o discurso, segundo Labov (op. cit. $1972^{12}$ ), e que a cultura influencia na construção do discurso, de acordo com Matthiessen \& Thompson (1988, p. 275-329), proposição esta já salientada na fundamentação teórica deste trabalho. A maior ou menor incidência de ocorrência das construções adverbiais decorre do fato de o discurso ser oral (conexões implícitas) ou escrito (conexões explícitas) e, dependendo também, principalmente, do gênero do discurso adotado pelo falante.

Tais análises demonstram o porquê da escassez de ocorrências das construções concessivas, como também os fatores que proporcionam uma maior produtividade para análise desse tipo de construção, explicando nossa

\footnotetext{
${ }^{12}$ Labov, W. Language in the inner city. Philadelphia, University of Pennsylvania Press, 1972.
} 
intuição inicial e justificando a nossa escolha para a análise das contruções complexas concessivas.

\subsection{Metodologia: seleção de dados}

Os estudos sobre as construções concessivas baseiam-se na presença do conector subordinativo concessivo. Buscamos, então, fazer um levantamento dos conectores citados e analisados por diferentes autores, apresentados a seguir:

\begin{tabular}{|c|c|c|c|}
\hline $\begin{array}{l}\text { Mira Mateus et al. } \\
(1983, \text { p. } 470-474)\end{array}$ & $\begin{array}{c}\text { Cunha e Cintra } \\
(1985, \text { p. } 572)\end{array}$ & $\begin{array}{c}\text { Neves } \\
(2000, \text { p. 862-864) }\end{array}$ & $\begin{array}{c}\text { Bechara } \\
(2003, \text { p. 327) }\end{array}$ \\
\hline Ainda que & Ainda que & Ainda quando & Ainda que \\
\hline Apesar de que & Apesar de que & Ainda que & Apesar de que \\
\hline Apesar de tudo & Bem que & Apesar (de) que & Embora \\
\hline Apesar disso & Conquanto & Conquanto & Posto que \\
\hline Conquanto & Embora & Embora & Se bem que \\
\hline Embora & Mesmo que & Mesmo que & \\
\hline Mesmo que & Nem que & Não obstante & \\
\hline Mesmo se & Por mais que & Nem que & \\
\hline Por mais que & Por menos que & Por mais que & \\
\hline Por muito... que & Posto que & Por menos que & \\
\hline Posto que & Que & Por muito que & \\
\hline \multirow[t]{2}{*}{ (Se) bem que } & Se bem que & Posto que & \\
\hline & & Se bem que & \\
\hline
\end{tabular}

O primeiro item que chama a atenção nessa tabela é a quantidade de locuções conjuntivas acompanhadas de "que". Nos compêndios gramaticais pesquisados a proporção é de Mira Mateus (7/10), Cunha e Cintra (10/10), Neves (9/11) e Bechara (4/4), excluindo-se neste caso conjunções características da concessão, como embora e conquanto - esta não encontrada no corpus analisado - que não formam uma locução conjuntiva.

O segundo item relevante neste levantamento é a citação de casos como o "que". O uso do "que" como prototípico de subordinação, já havia sido 
mencionado em Bechara (2003), agora Cunha e Cintra (1985) caracterizam-no como conjunção concessiva, porém sem possuir marca morfológica para isso, o que nos leva a considerar que o critério de seleção tenha sido pelo valor prototípico de subordinação expresso pelo "que", aliado ao valor semântico da sentença no momento de enunciação.

Com esse levantamento, fizemos uma busca nas 566 cartas de redatores e de leitores, para verificação de que tipo de conector apareceria. Para isso, consideramos as possíveis variações para conector e pesquisamos as opções dadas pelos autores consultados.

\begin{tabular}{|l|l|c|c|}
\hline & \multicolumn{1}{|c|}{ Conector } & No Ocorrências & $\%$ \\
\hline 1. & Ainda que ${ }^{13}$ & 24 & 31,2 \\
\hline 3. & Ainda quando & & \\
\hline 6. & Embora & 30 & 38,9 \\
\hline 7. & Mesmo que & 1 & 1,3 \\
\hline 9. & Nem que & 1 & 1,3 \\
\hline 10. & Por mais que & 3 & 3,9 \\
\hline 11. & Por menos que & 1 & 1,3 \\
\hline 12. & Posto que & 4 & 5,2 \\
\hline 13. & (Se) bem que & 10 & 13 \\
\hline & TOTAL & $\mathbf{7 7}$ & $\mathbf{1 0 0}$ \\
\hline
\end{tabular}

Os dados do quadro mostram que nem todos os conectores classificados como concessivos pelas gramáticas estudadas apareceram no levantamento efetuado nos jornais oitocentistas, o que talvez revele que sejam formas em desuso nesse gênero.

Inclusive, se considerarmos a porcentagem de ocorrências de alguns conectores no corpus percebe-se que as formas em prestígio como características de concessão ainda são: ainda que $(31,2 \%)$ e embora $(38,9 \%)$,

\footnotetext{
${ }^{13}$ Do total de 24 ocorrências para ainda que, acompanhado de verbo ou não, consideramos sete ocorrências com a forma ainda mesmo que, vista por nós como uma variação enfática da forma original devido ao uso de mesmo.

${ }_{14}$ Consideramos nesse total de seis ocorrências, uma com a forma ainda mesmo quando, pois consideramo-la também como uma variação enfática.

${ }^{15}$ Assim como Mira Mateus (1983, p. 470-474), consideramos se bem que e bem que como variações da mesma locução conjuntiva.
} 
que totalizam $70,1 \%$ do total de ocorrências do corpus, o que mostra que as demais formas foram pouco usadas para demonstrar 0 movimento argumentativo de concessão, nesse material e durante esse período.

Depois de localizadas as ocorrências nas cartas oitocentistas, efetuamos um recorte do complexo concessivo de cada carta. Para esse recorte, consideramos um enunciado completo, com um contexto mínimo e o complexo concessivo por inteiro. A seguir, temos o processo de recorte com a carta 316, de Pernambuco:

a) Localização da ocorrência e recorte do contexto de enunciação:

\author{
Carta 316 \\ Estado/Cidade: PE/ Recife \\ Tipo de Texto: Carta de Redator \\ Título do Jornal: Diário de Pernambuco \\ Data/Edição: Recife, sábado, 17 de outubro de 1868/ nº 238 \\ Fonte/Cota: Arquivo Biblioteca Nacional/Acervo do Laboratório de Pesquisa e de Ensino de \\ História da Universidade Federal de Pernambuco
}

DIARIO DE PERNAMBUCO || Abrimos hoje em nossas columnas um novo titulo debaixo do qual devem ser publicado os artigos politicos do partido conservador. \| Não é de hoje que o Diario de Pernambuco é affeiçoado as idéas que representam esse partido nem ainda é de agora que os escriptos conservadores acham espaço nas nossas columnas. I| Dando-lhes lugar reservado, sob um titulo especial, só tivemos em vista acquescer aos desejos daquellas que dirigem a politica constituicional na provincia, pondo-os à ressalvo das responsabilidades moral que por ventura possa caber áquelles que escrevem sob suas proprias e especiaes impressões. || Do que levamos dito, não se queira concluir que somos solidarios com todas as idéas que venham a ser emitidas nos escriptos à que alludimos. II Bem que estejamos de acordo nos principios, é possivel que entre esta redacção e os escriptores do partido conservador appareçam divergencias, que no modo pratico de levar a effeito algumas de suas idéas, que mesmo na concepçào d'estas. E', pois, para pormo-nos à coberto de uma responsabilidade, que não podemos nem devemos assumir, que declaramos que em artigos politicos, como em tudo mais que se publica no nosso jornal, só se nos deve fazer pesar sobre os hombros aquillo que for meramente da redacção ou collaboração do Diario, e que será, como tem sempre sido, publicado sob o titulo que cobre esse artigo, sob o de Revista Diaria e sob os de Interior e Exterior, e, neste caso, quando ainda protegidos pelo de correspondencia do Diario. || O diario não é, nem tem pretenções á ser jornal politico: a politica é para elle um acessorio, que provém necessariamente das idéas de seus redactores, e de sua posição no jornalismo, onde sempre se agitam mais ou menos as questões de ordem politica, como as de outra qualquer. || Foi reservando-nos o direito de emitir juizo pró ou contra qualquer acto do governo ou qualquer resolução ou idéa do partido, que aceitaremos quaesquer outros que nos convenha publicar, sem que com isso assumimos a sua responsabilidade moral. || Repetimos, pois, que só se nos deve fazer carga dos artigos edictoriaes, e por estes, sómente por estes, responderemos perante a opinião publica. || Quando nos accusar menos procurarem cobrir de lama aquelles que tem esse meio como ambiente, baseando-se em artigos que nada tem comnosco, o nosso silencio será a unica resposta cabivel; quando, porém, se dirigirem a nós em termos decentes e por aquillo que cobrimos com o nosso nome então achar-nos-hão sempre de lança emristada, no campo da honra, aquelles que o sabem e podem trilhar sem deixar vestigios de charcos. $\|$ Eis o que nos cumpria dizer ao abrirmos o titulo de - POLITICA INTERNA - partido conservador - no nosso jornal. 
b) Composição da ocorrência para análise:

(127) [...] Do que levamos dito, não se queira concluir que somos solidarios com todas as idéas que venham a ser emitidas nos escriptos à que alludimos. II Bem que estejamos de acordo nos principios, é possivel que entre esta redacção e os escriptores do partido conservador appareçam divergencias, que no modo pratico de levar a effeito algumas de suas idéas, que mesmo na concepçào d'estas. [...]

(Carta 316 - PE/Recife/CR/Diário de Pernambuco/1868)

Os itens a e b exemplificam o processo que efetuamos para cada uma das ocorrências com os conectores concessivos. A identificação das ocorrências foi feita com a indicação de: número da carta, Estado, cidade, carta de redator $(C R)$ ou carta de leitor $(C L)$, nome do jornal e ano de publicação.

Após a organização da primeira coleta de ocorrências, eliminamos os seguintes casos:

i) Locuções aparentemente conjuntivas:

(9) [...] he esta mesma Provincia | que neste mizeravel e lastimoso esta- | do, em dias poucos aprompta mil e cem [ilegível] ao arado e artes; e | [ilegível] deixando tantas Mãis, tantas espozas | Sem filhos, sem maridos desdirozas!! || $\mathrm{He}$ alli mesmo que pequenos e exhaustos Negociantes fazem ofertas, que | em poucos dias, já passavão de cem mil | cruzados para se apromptar a Tropa; a | qual precizando de hum fardamento, foi em poucos dias apomptado pelas Se- | nhoras Paulistas de todas as classes, que | espontaneamente se oferecerão! [...]

(Carta 341 - RJ-Rio de Janeiro/CR/Compilador Constitucional Político e Litterario/1822).

Em (9), pela entonação da frase e por seus elementos sintáticos, é possível perceber que a seqüência "mesmo que" não constitui uma locução conjuntiva de valor concessivo.

ii) Expressões com valor concessivo, mas que não configuram combinação de oração:

(10) Nada | mais lhe levaram, e ainda não se sabe á quem | se deve esta ousadia. A policia anda vigilante, | e apezar d'isso apparecem d'estes casos! Será | acaso porque as patrulhas gostam de dormir?

(Carta 51 - BA-Salvador/CR/Jornal da Bahia/1854) 
Casos com "apesar de" ou "apesar disso", como o exemplo (10), foram desconsiderados para análise, visto que não introduzem oração concessiva. No exemplo acima, temos o "e" executando a função de junção de orações coordenativas e o "apezar d'isso", com função de adjunto ${ }^{16}$.

A partir da quantidade de ocorrências, assim como da variedade destas, foram estabelecidos alguns fatores para observação e análise das construções complexas concessivas. A possibilidade de esses fatores serem determinantes para uma caracterização desse tipo de construção se dá, na medida em que permitem um panorama sintático funcional das ocorrências localizadas.

Utilizamos alguns fatores de análise que serviram como parâmetros nos trabalhos de Mira Mateus et al. (1983), Neves (1999 e 2000), Rodrigues et al. (1999) e Sweetser (1990), por constituírem referências proveitosas para a análise do item em questão. Os fatores determinados foram: 1 . Modo verbal da construção concessiva; 2. Tipo de conector utilizado; 3. Classificação das construções contrastivas; 4. Ordenação do complexo concessivo; 5. Possibilidade de inversão de ordem; 6. Correlação modal entre oração nuclear e oração concessiva; 7. Correlação temporal entre oração nuclear e oração concessiva; 8. Domínios de leitura; 9. Polaridade entre as orações nuclear e concessiva; 10. Predicação da construção concessiva; 11. Tipo de autor; 12. Período do século XIX.

Os dados foram submetidos a tratamento estatístico com a utilização do pacote de programas Goldvarb (Variable Rule Analysis).

\footnotetext{
${ }^{16}$ Os adjuntos adverbiais com valor de concessão constituem um rico tema para um próximo estudo.
} 


\section{Análise dos dados}

O objetivo deste trabalho é o de promover uma descrição do uso das construções concessivas na imprensa brasileira do século XIX. Para tanto, não desprezamos as ocorrências de construções concessivas desacompanhadas de verbo, razão pela qual teremos três seções de análise: a primeira (4.1) em que se descrevem as construções concessivas com conectores e verbo conjugado; a segunda (4.2) em que são analisadas as construções concessivas com conectores e sem verbo; a terceira (4.3) em que são analisados os fatores extra-lingüísticos.

Desse modo, poder-se-á descrever as correlações entre as condições de uso e o uso das construções concessivas no século XIX, destacando, assim, o padrão do Português Brasileiro escrito para esse fenômeno naquele período.

\subsection{As construções concessivas acompanhadas de verbo flexionado}

Consideramos o modo verbal como variável dependente para geração dos cálculos estatísticos no programa Goldvarb e utilizamos variáveis independentes que visam à caracterização lingüística das concessivas e outras que consideram o contexto extralingüístico da concessão, sendo também produtivas para uma descrição dos processos de expressão da concessão nas ocorrências coletadas.

\subsubsection{Tipo de conector}

A freqüência de uso dos conectores concessivos introduzindo orações com indicativo e subjuntivo aparece na relação que segue ${ }^{17}$ :

\footnotetext{
17 O pacote de programas Goldvarb desconsidera as casas após a vírgula e não faz arredondamentos, por isso muitas vezes a porcentagem fica somente próxima a 100\%.
} 


\begin{tabular}{|l|l|l|c|}
\hline Tipo de Conector & \multicolumn{2}{|c}{ Freqüência } & TOTAL \\
& Subjuntivo & Indicativo & \\
\hline Ainda que & $15 / 20=75 \%$ & $5 / 20=25 \%$ & $20 / 59=33 \%$ \\
\hline Ainda quando & $2 / 3=66 \%$ & $1 / 3=33 \%$ & $3 / 59=5 \%$ \\
\hline Embora & $19 / 21=90 \%$ & $2 / 21=9 \%$ & $21 / 59=35 \%$ \\
\hline Mesmo que & $1 / 1=100 \%$ & $0 / 1=0 \%$ & $1 / 59=1 \%$ \\
\hline Nem que & $1 / 1=100 \%$ & $0 / 1=0 \%$ & $1 / 59=1 \%$ \\
\hline Por mais que & $3 / 3=100 \%$ & $0 / 3=0 \%$ & $3 / 59=5 \%$ \\
\hline Por menos que & $1 / 1=100 \%$ & $0 / 1=0 \%$ & $1 / 59=1 \%$ \\
\hline Posto que & $3 / 3=100 \%$ & $0 / 3=0 \%$ & $3 / 59=5 \%$ \\
\hline (Se) bem que & $5 / 6=83 \%$ & $1 / 6=16 \%$ & $6 / 59=10 \%$ \\
\hline TOTAL & $\mathbf{5 0 / 5 9 = 8 4 \%}$ & $\mathbf{9 / 5 9 = 1 5 \%}$ & $\mathbf{5 9 / 5 9 = 1 0 0 \%}$ \\
\hline Tabela 1: Conectores concessivos & &
\end{tabular}

A leitura da tabela 1 permite a interpretação de dois tipos de informação. O primeiro tipo é em relação aos conectores concessivos mais freqüentes nos jornais oitocentistas, a saber: embora (35\%), ainda que (33\%) e (se) bem que (10\%). O uso de embora e de ainda que apresentou-se quase equivalente, o que pode sugerir que não havia preferência de uso do embora, informação esta evidente nos estudos sobre as construções concessivas, com dados do século $X X$.

Neves (1999, p. 573), ao analisar a língua falada de informantes que se utilizam da norma culta, detecta que os conectores concessivos mais utilizados são: embora $(47,27 \%)$, se bem que $(21,82 \%)$, mesmo que $(10,92 \%)$. O conector ainda que apresenta-se só em $5,45 \%$ daquele corpus, o que causa um estranhamento se considerarmos a quantidade de ocorrências do século XIX, podendo ser um indício de que esse tipo de conector concessivo possa estar entrando em desuso ou sendo usado com outra função.

O segundo tipo de informação que pode ser levantado a partir da interpretação da tabela é com relação à forma verbal que acompanha os conectores concessivos. Em 100\% das construções concessivas introduzidas pelos conectores mesmo que, nem que, por mais que, por menos que, posto que, o modo verbal utilizado é o subjuntivo. Mesmo considerando o pequeno número de ocorrências para cada conector, mostra-se uma informação produtiva se compararmos ao modo indicativo, pois outros 
conectores como ainda que, embora e (se) bem que, possuem respectivamente $75 \%$, 90\% e 83\%, de suas ocorrências também nesse modo, apesar das pequenas incidências no modo indicativo. Por outro lado, a freqüência de uso de conectores concessivos associados ao modo indicativo é bastante baixa.

Para exemplificar o que seria um conector acompanhado de verbo no modo indicativo ou subjuntivo, escolhemos duas ocorrências de (se) bem que ${ }^{18}$ para observação:

(11) [...] Lamento, porém, que Vossa Senhoria | não esteja bem informado de todos | os acontecimentos para delles dar | noticia aos seus innumeros leito- | res. || Se bem que em todos elles eu | não veja a independencia e ener- | gia que em taes circunstancias ca- | bia tomar a imprensa que defende | os principios e não o interesse de | balcão, todavia calou-me no espi- | rito o seu artigo de $1^{\circ}$ do cor- $\mid$ rente. [...]

(Carta 386 - RJ-Rio de Janeiro/CR/Diário do Brazil/1881)

(12) [...] Não é que | eu censure a Vossa mercê Senhor Redactor por inse- | rir um semelhante annuncio; bem que o | seu fim e até a sua promessa explicita foi | de illustrar ao publico e concorrer para a | sua felicidade com doutrinas saãs e de u- | ma immediata utilidade, todavia lá n'um | canto de sua folha bem póde fazer annun- | cios. O meu azedume é contra o estilo con- | ciso com que Sua Excelência fez as suas des- I pedidas.

(Carta 391 - SP-São Paulo/CL/Farol Paulistano/1828)

Na ocorrência (11) temos um exemplo de construção concessiva com conector acompanhado de verbo no modo subjuntivo, já no exemplo (12) o mesmo conector se faz acompanhar de construção sintática com verbo no modo indicativo.

Portanto, o subjuntivo é o modo verbal utilizado com maior freqüência nas construções concessivas do corpus sob análise e os conectores embora e ainda que e (se) bem que são os mais utilizados nas construções concessivas dos jornais do século XIX, mostrando-se conectores prototípicos desse tipo de construção nesse período.

\footnotetext{
${ }^{18}$ Como mencionado na seção 3.4 , bem que e se bem que são analisados como variações de uma mesma forma lingüística.
} 


\subsubsection{Classificação das Construções Contrastivas}

Mira Mateus (1983, p. 306-309) classifica as construções concessivas como pertencentes à categoria das construções contrastivas, pois expressam uma contrajunção, que pode ser classificada como: factual, hipotética ou contrafactual.

Com essa análise é possível verificar o que cada construção complexa concessiva expressa: um contraste de valores, uma hipótese ou uma hipótese que contraria um fato.

\begin{tabular}{|l|c|c|c|}
\hline \multicolumn{1}{|c|}{$\begin{array}{c}\text { Construções } \\
\text { Contrastivas }\end{array}$} & Subjuntivo & Indicativo & \\
\hline Factuais & $33 / 41=80 \%$ & $8 / 41=19 \%$ & $41 / 59=69 \%$ \\
\hline Hipotéticas & $16 / 17=94 \%$ & $1 / 17=5 \%$ & $17 / 59=29 \%$ \\
\hline Contrafactuais & $1 / 1=100 \%$ & $0 / 1=0 \%$ & $1 / 59=1 \%$ \\
\hline $\begin{array}{l}\text { TOTAL } \\
\text { Tabela 2: Classificação das construções contrastivas }\end{array}$ & $\mathbf{5 0 / 5 9 = 1 5 , 3 \%}$ & $\mathbf{5 9 / 5 9 = 1 0 0 \%}$ \\
\hline
\end{tabular}

As construções concessivas classificadas como factuais totalizam $69 \%$ das ocorrências encontradas, o que demonstra que o complexo concessivo articula uma argumentação baseadas em um contraste de valores, uma contraexpectativa.

O modo verbal do subjuntivo foi o mais freqüente em construções contrastivas factuais, com $80 \%$. As construções hipotéticas ocorrem quase que exclusivamente com o verbo da concessiva no modo subjuntivo, num total $94 \%$ das ocorrências.

(13) Senhor redactor.-A instrucção publica | neste municipio tem tido um melhora | mento de admirar, e isto depois que é | inspector municipal o doutor Joaquim Bueno | Goularte Brum; e para que senão diga, | que é uma ironia, ahi vão os factos: o | professor de São João Nepomuceno esteve | com a aula fechada mais de um anno, e I justo com o sargento-mór Belchior de Pon | tes Rego e Figueiredo ensinando seus ne / tos, e no entanto que se encobrio a verda | de ao governo, só para esse feliz profes | sor não perder o emprego, embora o pu | blico estivesse privado por tão longo tem | po da aula, estando esse professor ganhan | do de um particular; [...]

(Carta 149 - MG-Ouro Preto/CL/Minas Geraes/1862) 
Na ocorrência (13) temos o tipo de construção mais comum no corpus trabalhado, uma construção constrastiva factual, que é portadora de um contraste de valores, baseados em fatos concretos.

No exemplo em questão, temos o comentário de um leitor do jornal Minas Geraes sobre o sistema de educação no município, o qual era representado por um professor que passou mais de um ano sem lecionar na escola pública, dando aulas somente para os netos do sargento-mor da região e que, mesmo assim, não foi desligado de seu cargo e continuou recebendo.

Os fatos apresentados, de modo irônico, mostram um claro contraste de valores, pois se o professor recebia do município, os alunos não tinham aula, o procedimento seria o de lecionar para todos do município, o que não ocorria.

(14) I| Eis, Senhor Redactor, quanto julgo do meu | dever declarar em abono da verdade, pro- | testando ao mesmo tempo não voltar a im- | prensa, ainda que alguem pretenda contra- | riar-me, pois que as pessoas que me conhe- | cem sabem que sou incapaz de faltar á ver- | dade. || Bahia 13 de março de 1869 || Anna Januaria de Souza Amaral.

(Carta 48 - BA-Salvador/CL/Jornal da Bahia/1869)

O exemplo (14) é um caso de construção concessiva hipotética, com o conector "ainda que" introduzindo uma oração concessiva acompanhada de verbo no modo subjuntivo.

O que existe apenas como possibilidade é o fato de alguém vir a contrariar a opinião da leitora, o que ela espera não acontecer, pois não falta com a verdade no que diz.

Os cálculos de freqüência mostram que as construções concessivas são, predominantemente, factuais, ou seja, expressam um contraste de valores ou uma contra-expectativa, informação esta também encontrada nas análises de Neves (1999, p. 582) que detectou 37 das 55 (67,2\%) ocorrências analisadas expressando esse contraste de valores.

Ao relacionarmos a função contrastiva predominante ao conector utilizado na construção concessiva, temos a seguinte informação: 


\begin{tabular}{|l|c|c|c|c|}
\hline $\begin{array}{l}\text { Conectivo e } \\
\text { Funcão Contrastiva }\end{array}$ & Factual & Hipotética & Contrafactual & TOTAL \\
\hline Ainda quando & $2 / 3=66 \%$ & $1 / 3=33 \%$ & $0 / 3=0 \%$ & $3 / 59=5 \%$ \\
\hline Ainda que & $7 / 20=35 \%$ & $12 / 20=60 \%$ & $1 / 20=5 \%$ & $20 / 59=33 \%$ \\
\hline Embora & $21 / 21=100 \%$ & $0 / 21=0 \%$ & $0 / 21=0 \%$ & $21 / 59=35 \%$ \\
\hline Mesmo que & $0 / 1=0 \%$ & $1 / 1=100 \%$ & $0 / 1=0 \%$ & $1 / 59=1 \%$ \\
\hline Nem que & $1 / 1=100 \%$ & $0 / 1=0 \%$ & $0 / 1=0 \%$ & $1 / 59=1 \%$ \\
\hline Por mais que & $1 / 3=33 \%$ & $2 / 3=66 \%$ & $0 / 3=0 \%$ & $3 / 59=5 \%$ \\
\hline Por menos que & $0 / 1=0 \%$ & $1 / 1=100 \%$ & $0 / 1=0 \%$ & $1 / 59=1 \%$ \\
\hline Posto que & $3 / 3=100 \%$ & $0 / 3=0 \%$ & $0 / 3=0 \%$ & $3 / 59=5 \%$ \\
\hline (Se) bem que & $6 / 6=100 \%$ & $0 / 6=0 \%$ & $0 / 6=0 \%$ & $6 / 59=10 \%$ \\
\hline TOTAL & $\mathbf{4 1 / 5 9 = 6 9 , 5 \%}$ & $\mathbf{1 7 / 5 9}=\mathbf{2 8 , 8} \%$ & $\mathbf{1 / 5 9}=\mathbf{1 , 7} \%$ & $\mathbf{5 9 / 5 9 = 1 0 0 \%}$ \\
\hline Tabela 3: Relação entre tipo de conector e função contrastiva & & \\
\hline
\end{tabular}

Os conectores concessivos mais freqüentes nas construções concessivas factuais são embora, nem que, posto que, (se) bem que, que apresentam essa função contrastiva. Nas construções concessivas hipotéticas (ou eventuais), conectores como ainda que, por mais/menos que são os mais freqüentes.

Tais constatações demonstram que cada tipo de conector estabelece relações de preferência com determinadas construções contrastivas. Para os conectores prototípicos do século XIX, temos o embora e o (se) bem que usados em construções factuais e o ainda que usado, preferencialmente, em construções hipotéticas.

Esses dados confirmam a análise de Neves (1999, p. 589) de que é a escolha do tipo de contraste que se quer estabelecer, a partir da classificação em factuais, hipotéticas e contrafactuais, que determina o tipo de conector empregado na oração concessiva.

\subsubsection{Ordenação do Complexo Concessivo}

A posição da oração concessiva no complexo concessivo, introduzido por conectores, mostra-se importante na medida em que é um item que evidencia as peculiaridades dessas construções. 
São três os tipos de posição das orações concessivas que levaremos em consideração: anteposta (a), posposta $(p)$ ou intercalada (i), em relação à oração nuclear.

\begin{tabular}{|l|c|c|c|}
\hline \multirow{1}{*}{ Oração Concessiva } & \multicolumn{2}{c|}{ Freqüência } & TOTAL \\
\hline Anteposta & Subjuntivo & Indicativo & \\
\hline Posposta & $17 / 18=94 \%$ & $1 / 18=5 \%$ & $18 / 59=30 \%$ \\
\hline Intercalada & $21 / 26=78 \%$ & $5 / 26=21 \%$ & $26 / 59=44 \%$ \\
\hline $\begin{array}{l}\text { TOTAL } \\
\text { Tabela 4: Posição da oração concessiva }\end{array}$ & $12 / 15=80 \%$ & $3 / 15=20 \%$ & $15 / 59=25 \%$ \\
\hline
\end{tabular}

Pelos resultados dos cálculos de freqüência, podemos dizer que a posição preferencial das orações concessivas, em relação à oração nuclear, é a posposta, com a oração nuclear sucedida pela oração concessiva, em $44 \%$ das ocorrências, destacando-se a freqüência de 78\% para a posição posposta da oração concessiva, com o modo verbal no subjuntivo.

(15) [...] todavía as allusões e emphases com que taes pessôas eraõ designadas, poderiaõ dal-as a conhecer: e assim, naõ inserimos a correspondencia, por ser contra o nosso plano o admittir personalidades sempre odiosas por menos que sejaõ aggravantes. [...]

(Carta 408 - SP-São Paulo/CR/Farol Paulistano/1827)

(16) SENHOR Redactor - Queira Vossa mercê Aceitar | os parabens que por meio de sua folha dou | aos Guardas Nacionaes do Recife em con- | sequencia de já se achar criado o Conselho | de Disciplina, ainda que ignoramos quan- | do principiaráõ os seus trabalhos, no entre- | tanto o Senhor N. Zangado deve ter a glo- | ria de ter motivado esta execução da Ley; | aproveito esta ocasião para em duas pala- | vras responder ao seu anuncio do Diario d'| hoje a respeito do Senhor Breck-mesfreg, | que com toda a sua dignidade não pòde dei- | xar de mentir no momento em que lhe deu | a satisfação de não Ter visto o autografo da | sua mão visto que o contrario disse a pes- I soas muito capazes as quaes se for preciso | apareceráõ ao publico. || Seu venerado || O Nacional Moderado.

(Carta 267 - PE-Recife/CL/Diário de Pernambuco/1833)

(17) Esperar, que a promova o Governo, ocupado como está em tantos outros mil importantes trabalhos, e contra os principios de que não deve elle ser nunca agricultor, nem fabricante, embora o queira o Senhor Barata, he correr o risco de nunca a ver realizada.

(Carta 278 - PE-Recife/CR/A voz do Bebiribi/1835) 
Nas ocorrências (15), (16) e (17) temos, respectivamente, orações concessivas introduzidas por conectores nas posições de posposição, de anteposição e de intercalação com relação à oração nuclear. Independente da posição da oração concessiva, a maior incidência ainda é a do acompanhamento do verbo no modo subjuntivo.

Em (15), temos uma oração concessiva posposta à nuclear e podemos observar que existe uma asseveração de que naquele jornal não são inseridas personalidades polêmicas (odiosas), ainda que não tenham feito nada de tão grave, o que pressupõe uma possível defesa a uma objeção; o objetivo, então, para o uso da oração concessiva é o de expressar um afterthought, ou seja, uma informação colocada como um adendo, um complemento.

A ocorrência (16) apresenta uma oração concessiva posposta à oração nuclear e o conteúdo transmitido é o de um júbilo antecipado pela criação de um "Conselho de Disciplina" por parte dos "Guardas Nacionaes do Recife". A informação é a de que ainda não há previsão para o início do funcionamento do conselho, no entanto já é algo a ser comemorado. É possível observar que a oração concessiva tem a função de evidenciar a informação nova, atribuindo um valor de tópico para essa informação.

A oração concessiva intercalada na oração nuclear, como na ocorrência (17), tem a função de ressaltar uma informação da primeira parte da oração nuclear, pois "não deve elle ser nunca agricultor...". Este caso mostra que a oração concessiva "enfatizou" a informação da primeira parte da oração nuclear, antecipando ainda mais uma possível objeção, que em (17) poderia ser algo como "o desejo do Senhor Barata é que deve ser levada em consideração".

Nos estudos de Neves (1999), a proporção entre orações concessivas pospostas, antepostas e intercaladas à oração nuclear é de predomínio da posição da concessiva posposta (70,9\% dos casos), sendo que a posição de concessiva anteposta (20\%) e da concessiva intercalada $(9,1 \%)$ à oração nuclear apresentam-se com uma freqüência de uso muito menor. A autora aponta, então, que as construções concessivas, no geral, não apresentam uma função de tópico, mas de afterthought e, isso justificaria o predomínio de uso de orações concessivas pospostas à oração nuclear. 
Ao analisar as ocorrências do século XIX, nota-se que a soma de orações concessivas antepostas (30\%) e de orações concessivas intercaladas (25\%), totaliza $55 \%$ das 59 ocorrências, o que pode ser um indício de que nos textos escritos do século XIX a mobilidade de posição da oração concessiva em relação à oração nuclear era muito maior, sem fixar, portanto, uma posição prototípica.

Uma outra relação que pode ser estabelecida é entre o tipo de conector e a posição da oração concessiva:

\begin{tabular}{|l|c|c|c|c|}
\hline Posição e Conectivo & Anteposta & Posposta & Intercalada & TOTAL \\
\hline Ainda quando & $1 / 3=33 \%$ & $0 / 3=0 \%$ & $2 / 3=66 \%$ & $3 / 59=5 \%$ \\
\hline Ainda que & $8 / 20=40 \%$ & $7 / 20=35 \%$ & $5 / 20=25 \%$ & $20 / 59=33 \%$ \\
\hline Embora & $3 / 21=14 \%$ & $15 / 21=74 \%$ & $3 / 21=14 \%$ & $21 / 59=35 \%$ \\
\hline Mesmo que & $0 / 1=0 \%$ & $0 / 1=0 \%$ & $1 / 1=100 \%$ & $1 / 59=1 \%$ \\
\hline Nem que & $0 / 1=0 \%$ & $1 / 1=100 \%$ & $0 / 1=0 \%$ & $1 / 59=1 \%$ \\
\hline Por mais que & $2 / 3=66 \%$ & $1 / 3=33 \%$ & $0 / 3=0 \%$ & $3 / 59=5 \%$ \\
\hline Por menos que & $0 / 1=0 \%$ & $1 / 1=100 \%$ & $0 / 1=0 \%$ & $1 / 59=1 \%$ \\
\hline Posto que & $0 / 3=0 \%$ & $0 / 3=0 \%$ & $3 / 3=100 \%$ & $3 / 59=5 \%$ \\
\hline (Se) bem que & $4 / 6=66 \%$ & $1 / 6=16 \%$ & $1 / 6=16 \%$ & $6 / 59=10 \%$ \\
\hline TOTAL & $\mathbf{1 8 / 5 9 = 3 0 \%}$ & $\mathbf{2 6 / 5 9 = 4 4 \%}$ & $\mathbf{1 5 / 5 9}=\mathbf{2 5} \%$ & $\mathbf{5 9 / 5 9 = 1 0 0 \%}$ \\
\hline Tabela 5: Relação entre tipo de conector e posição & & &
\end{tabular}

Para ainda que e (se) bem que há uma diferença com relação aos dados de Neves $(1999, \text { p. } 573)^{19}$, pois neste estudo ambos são encontrados em orações concessivas pospostas, para embora a posição preferencial também é a da oração concessiva posposta.

Enquanto o uso do conector ainda que mostrou-se equilibrado em relação às posições na construção concessiva - tendo 8 (anteposição), 7 (posposição) e 5 (intercalada) casos -, o conector embora possui 74\% de seu uso em orações concessivas pospostas.

\subsubsection{Possibilidade de inversão na ordem}

A possibilidade de inversão da ordem das construções complexas concessivas é importante para verificação da hipótese de que as orações

\footnotetext{
${ }^{19}$ Vale lembrar que no estudo de Neves (1999) o material analisado foi o do corpus mínimo da Gramática do Português Falado (GPF), composto por 15 inquéritos do Projeto NURC.
} 
concessivas, desde que estivessem com verbo no modo subjuntivo, aceitariam inversão entre oração nuclear e oração concessiva sem alteração do conteúdo semântico. Tal hipótese explicaria a predominância de subjuntivo, devido à relação com a ordem da oração concessiva.

\begin{tabular}{|c|c|c|c|}
\hline \multirow{2}{*}{$\begin{array}{l}\text { Possibilidade de } \\
\text { inversão }\end{array}$} & \multicolumn{2}{|c|}{ Freqüência } & \multirow[t]{2}{*}{ TOTAL } \\
\hline & Subjuntivo & Indicativo & \\
\hline Sim & $35 / 39=89 \%$ & $4 / 39=10 \%$ & $39 / 59=66 \%$ \\
\hline Não & $15 / 20=75 \%$ & $5 / 20=25 \%$ & $20 / 59=33 \%$ \\
\hline TOTAL & $50 / 59=84 \%$ & $9 / 59=15 \%$ & $59 / 59=100 \%$ \\
\hline
\end{tabular}

Num primeiro momento, os dados da tabela parecem contraditórios, porém é importante observar as informações para a interpretação dos dados. A freqüência apresentada mostra que 39 das 59 ocorrências, o equivalente a $66,1 \%$ dos casos, permite inversão na ordem das orações sem prejuízo de seu conteúdo semântico.

(18) II Tenho por diviza a franquesa, e | alguns amigos mais particulares | sabem que não costumo negar os | meus feitos, ainda mesmo que | elles me custem o sacrificio da | propria vida. || A intriga vil e baixa que ali- | mentam certos individuos cobar- | des, esta eu a desprezo.

(Carta 67 - BA-Salvador/CL/Echo Sant'Amarense/1881)

(18a) Ainda mesmo que eles me custem o sacrifício da própria vida, tenho por divisa a franqueza e alguns amigos mais particulares sabem que não costumo negar os meus feitos.

$\mathrm{Na}$ ocorrência (18) temos uma oração concessiva posposta à oração nuclear, acompanhada de verbo no modo subjuntivo e, em (18a) temos a simulação de uma possível inversão da ordem da oração concessiva em relação à oração nuclear, neste caso, sem alteração do conteúdo semântico.

Das ocorrências com possibilidade de inversão, 89\% (35) trazem o verbo da oração concessiva no modo subjuntivo e 11\% (4) das ocorrências trazem o verbo no modo indicativo, o que demonstra que as orações concessivas no modo subjuntivo permitem inversão com maior facilidade.

Dos casos que aceitam inversão e estão no modo indicativo, foi observado o seguinte uso: 
(19) II Nas devaças geraes a que proce- | dem os Corregedores em correições | nas Cidades, e Villas do termo de suas | comarcas, inquirem testemunhas so- | bre aquellas pessoas que uzaõ do ti- | tulo de Dom sem lhes pertencer, em | consequencia de huma de nossas leys | a qual impoem penas as pessoas que | convencidas saõ de hum tal crime; | ora, se quem usa do titulo de Dom | sem Ihe pertencer he criminozo, o que será a Illustríssima Junta da Fazenda da Provincia, que exige o de Majestade Imperial, sem | que para isso esteja authorizada por | ley, alvará, ou decreto algum de legi- | tima authoridade ? || Ainda que muitas reflexões occor- | rem agora a minha imaginaçaõ sobre este objecto Senhor Redactor, para naõ ser | estenço, somente lançarei maõ das se- | guintes.

(Carta 264 - PE-Recife/CL/Diário de Pernambuco/1827)

(20) II Se me não entende o Leigo, ou | Jumento, que o mesmo he o que no| ta, como o que escreve; bem se vê | que isto he discorrer burricalmente | sem logica; pois de não entender não | se segue; que ninguem intenda, por- | que isso era querer regular a inteli- | gencia dos mais: quando o não en- | tender pode provir da curta esfera do Leitor: Diz que tenho boas inten- | ções. Não quero ser descortes, agra- | deço o elogio ainda que vem da mo- | derna boca da Burra da Ballaam. Se- | nhor Redactor ahi vai a Resposta, a | que lhe pedio papagueasse: sem | com tudo contractar correspondencias | com Burros; pois aqui me fico, e a | Vossa mercê he que, eu escrevo estas quatro regras. Outro sim, e por despedida | venha a saber o Asno, que muitas obras existem em meu poder (sem ser de pata) que a seu tempo pode- | rão apparecer.

(Carta 331 - RJ-Rio de Janeiro/CL/O Macaco Brasileiro/1822)

Tanto na ocorrência (19) como na ocorrência (20) temos uma intenção de uso do subjuntivo não realizada, o que resulta em falta de concordância na conjugação verbal.

(19a) Ainda que muitas reflexões ocorrem [ocorram] agora à minha imaginação sobre este objeto, senhor redator, para não ser extenso, somente lançarei mão das seguintes.

(19b) Senhor redator, para não ser extenso, somente lançarei mão das seguintes, ainda que muitas reflexões ocorrem [ocorram] agora à minha imaginação sobre este objeto.

(20a) Não quero ser descortês, agradeço o elogio, ainda que vem [venha] da moderna boca da Burra de Ballaam.

(20b) Ainda que vem [venha] da moderna boca da Burra de Ballaam, não quero ser descortês, agradeço o elogio.

Nas simulações de inversão (19b) e (20b), não há uma impossibilidade de inversão com prejuízo da compreensão, somente uma inversão com falta de concordância na conjugação verbal.

Para os casos de impossibilidade de inversão com o verbo da oração concessiva no modo subjuntivo, o que contrariaria a hipótese principal, pois das 
20 ocorrências com impossibilidade de inversão, com verbo da concessiva no subjuntivo, 13 trazem a oração concessiva intercalada à oração nuclear.

Na seção 4.1.3 observou-se que, se a oração concessiva apresenta-se intercalada na oração nuclear, a função dessa oração subordinada é a de agregar uma informação para a primeira parte da oração nuclear, promovendo assim uma antecipação ainda maior para uma possível objeção.

(21) [...] O simples offerecinento que faz o | Senhor Rangel de 13 Cidadãos, cujo merito e | capacidade eu reconheço (posto que não co- | nheça o ultimo de que falta) que o virão du- | rante o dia 13 nos Bairros do recife, parece | que não prova bem que não podia ter estado | tãobem nos afogados nesse dia, e concorrido | com algum serviço para quanto se tentava pôr | ali em pratica; [...] (Carta 279 - PE-Recife/CL/Diário de Pernambuco/1841)

(21a) * Posto que não conheça o último de que falta, o simples oferecimento que faz o senhor Rangel de 13 Cidadãos, cujo mérito e capacidade eu reconheço que o virão durante o dia 13 nos bairros do Recife.

(21b) * O simples oferecimento que faz o senhor Rangel de 13 Cidadãos, cujo mérito e capacidade eu reconheço que o virão durante o dia 13 nos bairros do Recife, posto que não conheça o último de que falta.

Uma ocorrência com oração concessiva intercalada (21) e duas tentativas de inversão: (21a) com anteposição da oração concessiva e (21b) com posposição da oração concessiva. Ambas as tentativas foram classificadas como agramaticais por perderem o valor de concessão ao se tornarem um amontoado de orações.

Rodrigues et al. (1999, p. 669), quando tratam da inversão das orações nuclear e concessiva, ressaltam que se a oração nuclear e a oração concessiva estabelecem uma correlação de modo indicativo/indicativo, a inversão torna-se pouco natural. Nesse caso não estaríamos diante de concessivas prototípicas.

Em resumo, com relação à inversão das orações nuclear e concessiva no complexo concessivo nos dados apresentados, há a predominância de possibilidade de inversão quando a oração concessiva traz um verbo no modo subjuntivo, ao passo que não há possibilidade de inversão nas seguintes situações: quando a oração concessiva apresenta-se intercalada na oração nuclear ou; quando a oração nuclear e a oração concessiva trazem verbos conjugados no modo indicativo. 


\subsubsection{Correlação Modal}

A correlação modal foi estabelecida considerando-se a ordem: oração nuclear e a oração concessiva - independente da posição que ocupe no complexo (se posposta, se anteposta ou se intercalada). As correlações estabelecidas foram: indicativo (nuclear) $x$ subjuntivo (concessiva); indicativo (nuclear) $x$ indicativo (concessiva) e subjuntivo (nuclear) $x$ subjuntivo (concessiva).

\begin{tabular}{|l|c|c|c|c|}
\hline Conector/Modo & Ind. I Subj. & Ind. I Ind. & Subj. I Subj. & TOTAL \\
\hline Ainda quando & 2 & 1 & - & 3 \\
\hline Ainda que & 15 & 5 & - & 20 \\
\hline Embora & 19 & 2 & - & 21 \\
\hline Mesmo que & 1 & - & - & 1 \\
\hline Nem que & 1 & - & - & 1 \\
\hline Por mais que & 3 & - & - & 3 \\
\hline Por menos que & 1 & - & - & 1 \\
\hline Posto que & 3 & - & - & 3 \\
\hline (Se) bem que & 4 & 1 & 1 & 6 \\
\hline TOTAL & 49 & 9 & 1 & 59 \\
\hline
\end{tabular}

Ao analisar os dados brutos do quadro, percebe-se que a correlação modal preferencial das ocorrências analisadas é verbo conjugado no modo indicativo na oração nuclear e verbo conjugado no modo subjuntivo na oração concessiva, pois 49 das 59 ocorrências trazem essa correlação.

(22) Quer os de um, quer os de outro | partido, os inculcados Democratas puros, e os | regressistas por excellencia, todos chamam cri- I mes e traições quaesquer actos, sem excepção, | do Governo, mesmo aquelles, em que a Lei | se não offende, e sim a prevenção de homens | ambiciozos e mal intencionados, que abusam da | credulidade das pessoas irrefectidas, para au| gmentarem a desconfiança contra o regimen ado- | ptado, e preparar a quèda daquelles Funcciona- | rios publicos, que elles querem substituir, ainda | que seja por poucos dias.

(Carta 31 - BA-Salvador/CR/Diário da Bahia - Político, Litterario, e Mercantil/1836) 
A ocorrência (22) mostra-se exemplar no que se refere aos dados sobre a correlação modal: modo indicativo na oração nuclear e modo subjuntivo na oração concessiva.

Rodrigues et al. (1999, p. 665) também sugerem que essa correlação modal seja a mais comum, uma vez que nos estudos realizados com material de língua falada, percebe-se essa mesma tendência, o que confirmaria a hipótese de que a correlação modal seja uma exigência sintática da construção do complexo concessivo.

\subsubsection{Correlação Temporal}

O estudo sobre a correlação dos tempos verbais das construções concessivas em Rodrigues et al. (1999) relaciona esses tempos a duas situações comunicativas básicas, a de narrar e a de comentar. Essa relação do narrar (mundo narrado) e do comentar (mundo comentado) foi proposto por Weinrich (1968 apud Rodrigues et al. 1999) para os tempos do modo indicativo e Rodrigues et al relacionam também aos tempos do modo subjuntivo. Analisar a correlação temporal relaciona-se diretamente a verificar que tipo de situação comunicativa (ou combinação) o interlocutor deseja estabelecer.

As correlações temporais presentes nos dados analisados foram esquematizadas no quadro a seguir:

\begin{tabular}{|l|l|}
\hline \multicolumn{1}{|c|}{ CORAÇÃO NUCLEAR } & \multicolumn{1}{|c|}{$\begin{array}{c}\text { ORAÇÃO CONCESSIVA } \\
\text { ORAÓn TEMPORAL }\end{array}$} \\
\hline Presente do Indicativo & $\begin{array}{l}\text { Pretérito Perfeito do Indicativo } \\
\text { Presente do Indicativo } \\
\text { Presente do Subjuntivo } \\
\text { Futuro do Subjuntivo }\end{array}$ \\
\hline Pretérito Imperfeito do Subjuntivo
\end{tabular}


A correlação temporal que se destaca é a do verbo no presente do indicativo na oração nuclear e no presente do subjuntivo na concessiva, $47,5 \%$ (28 das 59 ocorrências analisadas). Essa mesma relação modo-temporal foi detectada em Neves (1999, p. 570), com 40\% das ocorrências, enquanto nesta análise totaliza 47,5\% das ocorrências, já em Rodrigues et al (1999, p. 661), a predominância também é dessa correlação modo-temporal, sendo considerada a prototípica pelos autores, totalizando $30,6 \%$ (15/49) dos casos.

(23) | O Tramella, deitado, está furioso, di | zendo que conhece que é um gaudeiro, | um feijoeiro; mas que por esse mesmo | motivo deve ser considerado como pos | suidor das rendas necessarias, porque tu | do quanto faz é para empicuar; mas va | mos cá entre nós discutir: elle só em fal | lar, intrigar, e bater pernas; só em ser | espião do serralho, não arranja 200\$000 | 0 que achas?.. eu cá faço justiça ás mesas, | muito embora ella seja composta de | nossos adversarios.

(Carta 174 - MG-Ouro Preto/CL/Diario de Minas/1876)

O exemplo (23) seria então um exemplo da forma de correlação temportal de maior preferência. $O$ cruzamento das informações mais significativas da correlação modo-temporal e do tipo de conector utilizado, mostrou que para a oração nuclear no presente do indicativo e para a oração concessiva no presente do subjuntivo, as proporções foram:

\begin{tabular}{|l|c|}
\hline \multicolumn{1}{|c|}{ Tipo de conector } & $\begin{array}{c}\text { Tempo } \\
\text { verbal } \\
\end{array}$ \\
\hline & $\begin{array}{c}\text { Pres. Ind. } x \\
\text { Pres. Subj. }\end{array}$ \\
\hline Ainda quando & - \\
\hline Ainda que & $8 / 20$ \\
\hline Embora & $12 / 21$ \\
\hline Mesmo que & $1 / 1$ \\
\hline Nem que & $1 / 1$ \\
\hline Por mais que & $2 / 3$ \\
\hline Por menos que & $1 / 1$ \\
\hline Posto que & $2 / 3$ \\
\hline (Se) bem que & $1 / 6$ \\
\hline Total & $28 / 59$ \\
\hline
\end{tabular}


O conector embora é que mostra maior preferência de uso dessa correlação temporal, se considerarmos a quantidade de ocorrências. Ainda quando e (Se) bem que são os conectores que não apresentaram preferência no uso dessa correlação modal, no corpus analisado, o que também é detectado nos estudos de Rodrigues et. al. (1999, p. 665).

Os tempos do presente (do indicativo e do subjuntivo) correlacionados nas construções concessivas mostram que se pode fazer uma relação entre 0 uso sintático (verbal) e o gênero textual utilizado, para a realização de uma determinada intenção discursiva (ver seção 3.3) e, conseqüentemente, ao referido mundo comentado.

As construções concessivas analisadas nas cartas argumentativas revelam que a intenção comunicativa é a de que o autor faça comentários, debata, argumente, acrescente informações, emita opiniões sobre determinados assuntos, o que mostra a situação comunicativa do mundo comentado, com um intenso envolvimento emocional, tema esse já tratado na seção 3.2 sobre os graus de formalidade nas cartas de leitores e redatores.

\subsubsection{Domínios de Leitura}

A proposta de Neves (1999, p. 552) leva em consideração a teoria de Sweetser (1990) para uma interpretação semântica que pode ser utilizada para as construções concessivas. A interpretação da semântica da frase leva em consideração a análise das construções concessivas, a partir dos seguintes critérios: i) como um veículo portador de conteúdo; ii) como uma entidade lógica; iii) como instrumento de um ato de fala.

Nas construções concessivas analisadas, a relação estabelecida entre domínios de leitura e modo do verbo da oração concessiva, apresentou nos seguintes resultados:

\begin{tabular}{|c|c|c|c|}
\hline \multirow{2}{*}{ Domínios de Leitura } & \multicolumn{2}{|c|}{ Freqüência } & \multirow[t]{2}{*}{ TOTAL } \\
\hline & Subjuntivo & Indicativo & \\
\hline Domínio Epistêmico & $38 / 46=82 \%$ & $8 / 46=17 \%$ & $46 / 59=77 \%$ \\
\hline Domínio do Conteúdo & $11 / 12=91 \%$ & $1 / 12=8 \%$ & $12 / 59=20 \%$ \\
\hline Domínio dos Atos de Fala & $1 / 1=100 \%$ & $0 / 1=0 \%$ & $1 / 59=1 \%$ \\
\hline TOTAL & $50 / 59=84 \%$ & $9 / 59=15 \%$ & $59 / 59=100 \%$ \\
\hline
\end{tabular}


O domínio epistêmico, que envolve processos mentais (de raciocínio), pois a partir de premissas o falante chega a determinadas conclusões, possui 0 maior número de ocorrências do corpus (38/59=64,4\%), o que demonstra que a natureza pragmática das construções concessivas valoriza os processos mentais presentes numa argumentação.

Para Neves (1999, p. 588), essa natureza argumentativa é o que aproxima as construções concessivas das construções adversativas, afinal as duas codificam com maior freqüência a oposição entre pensamentos. Existem, então, de acordo com Moeschler e Spengler (1981, apud Neves 1999) duas possibilidades de uso para a concessão: a lógica (equivalente ao domínio do conteúdo) e a argumentativa (equivalente ao domínio epistêmico e ao domínio dos atos de fala), sendo a primeira responsável pela relação de causalidade e de condicionalidade e a segunda responsável pela relação de adversidade na construção concessiva.

Das 59 construções concessivas analisadas, 47 corresponderiam à concessão argumentativa e somente 12 corresponderiam à concessão lógica, corroborando os dados sobre a tendência da construção concessiva de elaborar processos mentais de análise e construção de argumentos por parte do falante/autor para uma possível objeção.

(24) Secção para todos || Do Senhor Apulcho Castro, proprie- | tário do Corsario, recebemos a se- | guinte carta: \| $<<$ Senhor Redactor do Jornal da | Noite, Tenho nestes ultimos | dias, lido o seu popular jornal. || Lamento, porém, que Vossa Senhoria | não esteja bem informado de todos | os acontecimentos para delles dar | noticia aos seus innumeros leito- | res. || Se bem que em todos elles eu | não veja a independencia e ener- | gia que em taes circunstancias ca- | bia tomar a imprensa que defende | os principios e não o interesse de | balcão, todavia calou-me no espi- | rito o seu artigo de $1^{\circ}$ do cor| rente. [...]

(Carta 386 - RJ-Rio de Janeiro/CR/Diário do Brazil/1881)

Em (24) temos uma construção concessiva no domínio epistêmico, na qual existe um processo mental argumentativo. $O$ redator do jornal transcreve uma carta recebida de um leitor e este elabora uma argumentação sobre as notícias publicadas, os acontecimentos recentes, os interesses políticos do jornal e, principalmente, sua postura perante um determinado artigo. Fica claro, pois, que o conteúdo expresso na oração nuclear contraria a conclusão 
induzida pela oração concessiva, característica essa importante para a caracterização desse tipo de proposição.

Ao contrário dos dados de Neves (1999, p. 557) que apresentam o domínio do conteúdo como de menor preferência, em nossos dados esse domínio é responsável por 20,3\% das ocorrências (12/59), o que pode estar relacionado à natureza do tipo de texto. No domínio do conteúdo ocorre uma relação entre fatos e eventos de um mundo possível, possuindo em sua natureza uma frustração de expectativa de causalidade ou de condicionalidade, características essas que se relacionam ao próprio tipo de texto utilizado: cartas argumentativas. Leiamos o exemplo abaixo:

(25) II Mas pedem aquelles peticionarios a | compra de um terreno no logar denomi- | nado Guarapuavinha que tem por divisas | as serras da Esperança e da Alegria, e por | outro lado a serra ou o rio do Iguassú, e | embora sejam um pouco obscuras estas | divisas, por não existir neste sertão outra | serra que não seja a da Esperança com suas | ramificações, accresce que o território do | municipio, districto ou parochia da cidade | de Ponta Grossa, não tem nestas regiões | em parte alguma por limites o rio Iguassú, | dividindo-se com a comarca de Guarapua- | va pelo rio dos Patos até suas cabeceiras, | e d'ahi a rumo a incontrar as divisas do | territorio da villa da Palmeira.

(Carta 223 - PR-Curitiba/CL/O Dezenove de Dezembro/1878)

Na ocorrência (25) temos a relação entre dois eventos "solicitação de compra de um terreno próximo a serra da Esperança e ao rio Iguassú" e "constatação de que as divisas são obscuras, mas não o suficiente para não se conseguir localizar as referidas terras". Há a frustração de uma expectativa de causalidade, "o fato das divisas obscuras serem suficientes para a não localização do terreno", entre os fatos expressos nas orações concessiva e nuclear, estabelecendo uma relação lógica entre eles.

Considerando-se que a carta foi enviada por um leitor e que este leitor pretende "denunciar" algum desmando ou "esclarecer" algum fato, é compreensível que haja nesse tipo de textos mais relações entre fatos e eventos característicos do domínio do conteúdo, do que em relatos orais.

Em contrapartida, no domínio dos atos de fala houve uma única ocorrência nas cartas analisadas e, se considerarmos que esse domínio também tem uma natureza argumentativa, seria de se estranhar o porquê do domínio epistêmico ter muitas ocorrências e o domínio dos atos de fala não. 
Novamente, o contexto de produção desses textos pode sugerir uma explicação para isso. Em produção escrita, é mais difícil encontrarmos uma "auto-avaliação" do que foi dito, evento esse muito comum na oralidade, por isso o domínio dos atos de fala, no qual o falante faz uma auto-avaliação da inaptidão do ato de fala declarativo da oração nuclear, seria o menos utilizado nesse tipo de texto.

(26) || Eis, Senhor Redactor, quanto julgo do meu | dever declarar em abono da verdade, pro- | testando ao mesmo tempo não voltar a im- | prensa, ainda que alguem pretenda contra- | riar-me, pois que as pessoas que me conhe- | cem sabem que sou incapaz de faltar á ver- | dade. || Bahia 13 de março de 1869 || Anna Januaria de Souza Amaral.

(Carta 48 - BA-Salvador/CL/Jornal da Bahia/1869)

$O$ ato de fala expresso na ocorrência (26) demonstra essa autoavaliação, pois a leitora expressa sua defesa (um segundo ato de fala declarativo) antes mesmo de terminar a proposição da oração nuclear.

Analisando agora os resultados dos cálculos de freqüência, a partir da variável dependente determinada para tanto, o modo subjuntivo do verbo é o que acompanha prioritariamente quaisquer eventos que a oração concessiva possa expressar, seja no domínio epistêmico, seja no domínio do conteúdo ou seja no domínio dos atos de fala.

\subsubsection{Polaridade}

A construção concessiva pressupõe uma disjunção entre a oração nuclear e a oração concessiva; é de se esperar, então, uma relação de polaridade, negação e afirmação entre elas.

Analisamos nas construções concessivas a relação de polaridade entre a oração nuclear e a oração concessiva, com as seguintes classificações:

i) oração nuclear e oração concessiva negativas;

ii) oração nuclear negativa e oração concessiva afirmativa;

iii) oração nuclear e oração concessiva afirmativas;

iv) oração nuclear afirmativa e oração concesiva negativa. 


\begin{tabular}{|c|c|c|c|}
\hline \multirow{2}{*}{ Polaridade } & \multicolumn{2}{|c|}{ Freqüência } & \multirow[t]{2}{*}{ TOTAL } \\
\hline & Subjuntivo & Indicativo & \\
\hline Negativa $\times$ Negativa & $3 / 3=100 \%$ & $0 / 3=0 \%$ & $3 / 59=5 \%$ \\
\hline Negativa $\times$ Afirmativa & $16 / 20=80 \%$ & $4 / 20=20 \%$ & $20 / 59=33 \%$ \\
\hline Afirmativa $\times$ Afirmativa & $19 / 24=79 \%$ & $5 / 24=20 \%$ & $24 / 59=40 \%$ \\
\hline Afirmativa $\times$ Negativa & $12 / 12=100 \%$ & $0 / 12=0 \%$ & $12 / 59=20 \%$ \\
\hline TOTAL & $50 / 59=84 \%$ & $9 / 59=15 \%$ & $59 / 59=100 \%$ \\
\hline
\end{tabular}

Ao comparar os dados de freqüência apresentados na tabela acima com os dados de Neves (1999, p. 574), observa-se naquele trabalho não houve nenhuma ocorrência com polaridade negativa na oração nuclear e na oração concessiva, com predominância de 61,82\% (34/55 das ocorrências) para polaridade afirmativa em ambas as orações. Já nos nossos dados, há predominância de polaridade afirmativa na oração concessiva, com polaridade afirmativa ou negativa na nuclear, o que totaliza $73 \%$ dos casos, assim como $5 \%$ dos casos com a polaridade negativa em ambas as orações.

Os nossos resultados dos cálculos de freqüência demonstram que as construções concessivas podem apresentar-se preferencialmente, com polaridade negativa ou afirmativa na oração nuclear e polaridade afirmativa na oração concessiva, o que pode ser observado nos exemplos abaixo:

(27) Indo eu procurar em | algumas casas de negocio licenças para tirar, | respondeo-me um dono da casa: - meu | amigo, as minhas licenças eu as dou a um | guarda da camara para as tirar, | porque só assim fico descançado de multas e outros| incommodos, embora pague por cada uma | 3 ou 4 \$ réis, porque elles lá se entendem | uns com os outros; e dizendo a esse bom | homem que eu as tirava a 1 \$ réis, elle cal-|lou-se como preferindo pagar quadruplica-|damente, e eu disse com os meus botões: | ah, quem me dera ser guarda!

(Carta 354 - RJ-Rio de Janeiro/CL/O Despertador Municipal/1850)

(28) I| Tenho por diviza a franquesa, e | alguns amigos mais particulares | sabem que não costumo negar os | meus feitos, ainda mesmo que | elles me custem o sacrificio da | propria vida. || A intriga vil e baixa que ali- | mentam certos individuos cobar- | des, esta eu a desprezo.

(Carta 67 - BA-Salvador/CL/Echo Sant'Amarense/1881)

As ocorrências (27) e (28) são exemplos das estruturas que mais aparecem nas construções concessivas no que concerne à polaridade; a primeira compõe um conjunto de 24 ocorrências com as orações nuclear e 
concessiva afirmativas; a segunda, um grupo de 20 ocorrências com oração nuclear negativa e oração concessiva afirmativa.

Em (27) a asserção positiva vigora tanto na oração nuclear quanto na oração concessiva, mostrando que para haver uma quebra de expectativa, uma argumentação de idéias, não é necessário que exista alguma negação expressa.

A ocorrência (28) traz dois elementos de negação na oração nuclear, não (advérbio) e negar (verbo) e traz uma oração concessiva afirmativa, com um elemento enfático clivado na locução conjuntiva mesmo (advérbio), além de expressar uma frustação na oração nuclear negativa e uma inferência na oração concessiva afirmativa.

O próximo exemplo (29) ilustra o tipo de correlação de polaridade afirmativa na oração nuclear e negativa na oração concessiva.

(29) II A interferencia do Brasil em prol de qualquer dos contendores, ainda que esssa interferencia não se fizesse sentir senão como almejos de victoria para um delles, seria um erro gravissimo, por isso que faria preiallar os nossos mais caros interesses no Prata, sem contar que contribuirá para ainda mais desenfreiar os odios immerecidos de que se nos faz carga.

(Carta 327 - PE-Recife/CR/Diário de Pernambuco/1874)

$\mathrm{Na}$ ocorrência (30) temos as duas orações com polaridade negativa e, pela freqüência com que são usadas (3/59), percebe-se que não é uma construção comum, mesmo tendo o verbo da concessiva conjugado no modo subjuntivo, o que talvez fosse um facilitador.

(30) Como nao falta, quem julgue em | perigo o Universal, por ter dado lu | gar á defesa dos homens honrados | atrozmente calumniados pelo maldito | Paraopebano, apresso-me a transcrever | a seguinte Portaria para desengano | desses pobres illudidos, para que se não | persuadão, que o sabio Governo do Im | perio tolhe a liberdade da Imprensa, | ou approva arbitrios practicados com | os Escritores ainda quando suas dou | trinas não sejão conformes ás Leis, | porque neste caso há o recurso nellas | estabelecido.

(Carta 128 - MG-Ouro Preto/CR/O Universal/1825)

O predomínio da oração concessiva com polaridade afirmativa (44/59) mostra que o tipo de argumento introduzido por essa oração traz uma inferência afirmativa e a oração nuclear está ligada a uma frustração expressa pela nuclear negativa ou afirmativa, o que reforça o tipo de proposição expresso no domínio epistêmico. 


\subsubsection{Predicação}

Borba (1990) classifica os verbos com base em critérios sintáticosemânticos, o que resulta em uma análise não só da natureza dos papéis inerentes ao sentido básico do verbo, como também do arranjo estrutural em termos de categorias mórficas ou de tipos funcionais do verbo.

Os verbos analisados foram os que acompanhavam a oração concessiva e são classificados em: ação, processo, ação-processo e estado.

\begin{tabular}{|l|c|c|c|}
\hline \multirow{2}{*}{ Predicação } & \multicolumn{2}{|c}{ Freqüência } & TOTAL \\
\hline Ação & Subjuntivo & Indicativo & \\
\hline Processo & $4 / 8=50 \%$ & $4 / 8=50 \%$ & $8 / 59=13 \%$ \\
\hline Ação-Processo & $4 / 5=80 \%$ & $1 / 5=20 \%$ & $5 / 59=8 \%$ \\
\hline Estado & $13 / 16=81 \%$ & $3 / 16=18 \%$ & $16 / 59=27 \%$ \\
\hline $\begin{array}{l}\text { TOTAL } \\
\text { Tabela 9: Predicação }\end{array}$ & $\mathbf{5 0 / 5 9 = 8 4 \%}$ & $\mathbf{9 / 5 9 = 1 5 \%}$ & $\mathbf{5 9 / 5 9 = 1 0 0 \%}$ \\
\hline
\end{tabular}

Os verbos que expressam estado são aqueles nos quais há uma propriedade, uma condição ou uma situação localizadas no sujeito, como por exemplo alguns verbos utilizados nas orações concessivas: ter, ser, querer, haver, desejar e gozar. Os verbos que expressam estado foram os mais usados nas orações concessivas 50\% (30/59 dos casos) e, além de expressar estado, ainda estavam conjugados no modo subjuntivo.

A segunda maior freqüência de predicação na oração concessiva é para verbos que expressam ação-processo (27\%). Os verbos de ação-processo atuam sobre um complemento que expressa uma mudança de estado, de condição ou de posição, ou ainda, algo que começa a existir. São exemplos extraídos das orações concessivas: escrever, desaparecer, acrescentar, incomodar e mudar. 


\subsection{As construções concessivas sem verbo flexionado}

O levantamento das construções concessivas nas cartas do século XIX apresentou um número significativo de ocorrências nas construções concessivas, com conectores desacompanhados de verbo flexionado, 23,3\% do total $(18 / 77)$ de ocorrências.

Por ser um número significativo de ocorrências e pela novidade que configura esse tipo de construção, separamos uma seção específica para a análise desse tipo de uso. Alguns dos fatores utilizados na seção (4.1) serão utilizados, em conjunto, para descrição dessas expressões concessivas.

Com relação ao total de ocorrências, tipo de conector e posição que aparecem no enunciado, tem-se:

\begin{tabular}{|l|c|c|c|c|}
\hline CONECTOR & \multicolumn{3}{|c|}{ POSIÇÃO } & TOTAL \\
\cline { 1 - 5 } & Anteposta & Intercalada & Posposta & \\
\hline Ainda que & - & 4 & - & 4 \\
\hline Embora & - & 5 & 4 & 9 \\
\hline Posto que & - & - & 1 & 1 \\
\hline (Se) bem que & - & 3 & 1 & 4 \\
\hline TOTAL & - & $\mathbf{1 2}$ & $\mathbf{6}$ & $\mathbf{1 8}$ \\
\hline
\end{tabular}

Os conectores concessivos embora, ainda que e (se) bem que são os mais utilizados nesse tipo de construção, coincidentemente, são os que possuem a maior freqüência também, quando acompanhados de verbo (cf. tabela 1, seção 4.3.1).

A posição preferencial desse tipo de construção no material analisado é a intercalação da expressão com valor concessivo na oração nuclear, muitas vezes até mesmo com sinais de pontuação específicos para esse fim, como os parênteses e o travessão, o que mostra o caráter de informação adicional, esclarecimento que essa expressão com valor concessivo exerce sobre a principal. 
(31) ICreio que procedi em regra, e admiro | que a má fé tenha chegado ao ponto de | pretender-se lançar sobre mim aquillo | que outros fizeram, e eu puni logo como | me cumpria! || Quanto ao mais de que tracta o | mentiroso Imparcial, chamando-me ce- | lebre como si eu fosse algum famigera- | do traidor ou assassino desses que tanto | abundam pelo sertão e ás vezes reves| tidos com o caracter de auctoridades, eu o provoco solemnemente a vir á Im- | prensa - embora covardemente sob a ca- I pa do anonymo - declarar uma por uma | as bandalheiras que me empresta no seu | escripto e tudo o mais quanto entender | que me pode fazer carga. || Si não corresponder deste modo á pro- | vocação que lhe faço, ou si não levar | desses factos uma denuncia em fórma | aos meus superiores, permittir-me-ha | desprezal-o como merece o mais covar| de e infame calumniador ||

(Carta 42 - BA-Salvador/CL/Jornal da Bahia/1860)

A ocorrência (31) é um exemplo de construção sem acompanhamento de verbo na concessiva, estando esta ainda na posição de intercalada na oração nuclear e separada por travessão para isolamento da informação. "Vir à imprensa" denunciar algum tipo de corrupção ou fazer alguma acusação seria louvável caso o caluniador não se tivesse posto como "anônimo". A não validade de uma denúncia no anonimato é a informação nova que a oração concessiva insere, o mais rápido possível, no enunciado.

A partir da observação da posição da oração concessiva no enunciado, constatamos que não há possibilidade de inversão da ordem entre oração nuclear e a expressão com valor concessivo, em nenhuma posição.

(32) II Não podemos comprehender por li- | berdade de cultos o comparecimento | das auctoridades governantes, official- | mente, com apparato de tropas, a um | culto, desprestigiando-se os outros, como | si elles não existissem, embora em mi- | noria.

(Carta 74 - BA-Salvador/CL/Jornal de Noticias/1896)

(32a) * Embora em minoria, não podemos compreender por liberdade de cultos o comparecimento das autoridades governantes, oficialmente, com aparato de tropas, a um culto, desprestigiando-se os outros, como se eles não existissem.

O estranhamento na construção da sentença (32a) mostra-se por conta da "minoria" ressaltada na oração concessiva referir-se exclusivamente a "como se eles não existissem". Não é que os outros cultos religiosos não existam, apesar de as autoridades agirem dessa forma, mas que eles são em pequena quantidade. 
Com a ocorrência (32) podemos perceber que a expressão concessiva, neste caso é um sintagma nominal, atua sobre um item específico da oração nuclear, não atuando sobre o sentido da oração nuclear como um todo, sendo este o motivo semântico para a inadequação de uma inversão de posição.

As orações concessivas intercaladas na oração nuclear não permitem inversão, como consta na seção 4.1.4. Acresce-se ainda a essas características, uma outra exemplificada pela ocorrência abaixo, com uma expressão concessiva:

(33) Implantem-se no animo nacional | novos habitos, desperte-se, cultive-se e estenda | se a iniciativa individual, e a organisação admi | nistrativa, ainda permanecendo a mesma, justifi | car-se-ha da imputação que lhe hoje fazem. Ao | contrario, modifique-se essa organisação, refor | me-se a ainda que radicalmente, não se transfor | mando os habitos da população, nada haveremos | conseguido.

(Carta 89/2 - BA-Salvador/CR/Correio da Bahia/1876)

(33a) * Ainda que radicalmente, ao contrário, modifique-se essa organização, reforme-se-á, não se transformando os hábitos da população, nada haveremos conseguido.

(33b) * Ao contrário, modifique-se essa organização, reforme-se-á, não se transformando os hábitos da população, nada haveremos conseguido, ainda que radicalmente.

A impossibilidade de inversão em (33a) e (33b) deve-se também ao fato da expressão concessiva incidir sobre um único elemento da oração principal, no caso "reforme-se", impossibilitando mais ainda o jogo de posições entre oração concessiva e oração nuclear.

Ao analisar-se o tipo de construção contrastiva que as expressões concessivas sem verbo apresentam, tem-se o uso de 100\% das ocorrências expressando factualidade, ou seja, todas expressam uma contra-expectativa.

Outra constatação importante também é a de que, assim como as construções com expressão concessiva sem verbo flexionado são factuais, todas elas pertencem ao domínio epistêmico, como já pode ser visto nos exemplos (31), (32) e (33).

A relação do tempo verbal da oração nuclear, com o tipo de informação sintática da expressão concessiva, foi esquematizada da seguinte maneira: 


\begin{tabular}{|l|l|}
\hline \multicolumn{1}{|c|}{ Oração Nuclear } & Expressão Concessiva \\
\hline \multicolumn{1}{|c|}{ Tempo Verbal } \\
\hline Presente do Indicativo \\
Imperativo \\
Pretérito Perfeito do Indicativo \\
Pretérito Imperfeito do Indicativo \\
\hline Presente do Subjuntivo \\
\hline Pretérito Imperfeito do Subjuntivo \\
\hline Pretérito Perfeito do Indicativo \\
\hline Pretérito Perfeito do Indicativo \\
\hline
\end{tabular}

O tempo verbal da oração nuclear associa-se em 14 das 18 ocorrências, a um sintagma adjetivo, como mostram os exemplos a seguir:

(34) Asseguramos ao communicante supra que publicaremos a exposição do facto a que allude, uma vez que seja escripta em linguagem decente embora energica, e que venha acompanhada da responsabilidade legal. || $A$ Redação.

(Carta 498 - SP-São Paulo/CR/Correio Paulistano/1855)

(35) [...] notando aqui de passagem, que o es- | crivão da provedoria, tem direito á | minha gratidão, pois sendo elle brazi- | leiro nato, auxilia-me nos meios de | minha subsistencia e da de minha fa- | milia, ao mesmo tempo, q' de mãos | dadas com alguem, d'elles procura privar-me um homem de senti- | mentos miseraveis, á pouco naturali- | sado no paiz, onde nada tem que o | prenda, e que diz ser meu patricio; | mas o que Deos não permitta - Vade | retro ! Porém querem formar uma | idéa (se bem que mui distante) de quem | é esse + João Gomes dos Santos, | hoje procurador, nesta capital? [...] (Carta 451 - SP-São Paulo/CL/Correio Paulistano/1857)

Tanto na ocorrência (34), quanto na ocorrência (35) temos os adjetivos presentes na expressão concessiva, "enérgica" e "distante", atuando sobre um único elemento da oração nuclear, "linguagem" e "idéia", respectivamente.

Por fim, o jogo de polaridade entre a oração nuclear e a expressão concessiva reitera os dados de que a preferência de uso das construções concessivas é a de oração nuclear e oração concessiva com polaridade afirmativa, como visto na seção 4.1.8. 
Em todos os casos de expressões introduzidas por conectores concessivos e sem acompanhamento de verbo, a polaridade é afirmativa na concessiva.

Neves (1999, p. 566) menciona que a posposição da construção concessiva relaciona-se à natureza argumentativa e é necessária em casos em que a "ressalva" (a concessão) incide sobre um ponto particular de um sintagma adjetivo ou de um sintagma nominal. Pelos exemplos dados, nota-se que são expressões concessivas sem verbo e o comentário da autora ressalta o ponto de incidência da ressalva na oração nuclear, porém não há mais nenhum tipo de comentário sobre esse tipo de construção.

Ao analisarmos que tipo de elemento a expressão concessiva estaria ressaltando, temos: i) a ressalva sobre um elemento da oração nuclear (sintagma adjetivo ou sintagma nominal, como sugere Neves); ii) a ressalva sobre a oração nuclear como um todo.

(36) [...] Affirmava-se-me que era deliberado proposito do Centro Republicano deste Estado iniciar uma politica, se bem que accentuadamente democratica, toda de cordialidade e de plena confiança para com os sinceros neophytos da republica, para com os cidadãos que, sem reserva de pensamento, haviam lealmente adherido ao novo regimen e, por amor á ordem e á liberdade, concorriam para a consolidação delle em nossa patria. [...] (Carta 532 - SP-São Paulo/CR/Correio Paulistano/1890)

(37) II Não podemos comprehender por li- | berdade de cultos o comparecimento | das auctoridades governantes, official- | mente, com apparato de tropas, a um | culto, desprestigiando-se os outros, como | si elles não existissem, embora em mi- | noria.

(Carta 74 - BA-Salvador/CL/Jornal de Noticias/1896)

Nas ocorrências acima, em (36) a expressão concessiva faz uma ressalva sobre um substantivo "política" e em (37) sobre toda a oração nuclear.

(38) || Esses pardieiros arruinados, sem ar e sem o | asseio suficiente a evitar enfermidades, onde o | trabalhador repousa durante as horas do des- | canço, verdadeiros charcos de immundice, que | affrontam a capital do Imperio, porque não são extincotos e se manda construir em lugares | apropriados moradias, embora humildes, mas | limpas arejadas e sadias, onde os menos favo- | recidos da fortuna encontrem uma commodi- | dade ? || Continuar-se-há II A. Gaula

(Carta 375 - RJ-Rio de Janeiro/CL/Jornal de Noticias/1875) 
A ocorrência (38) é um exemplo do padrão de uso das expressões concessivas sem verbo flexionado, pois traz as seguintes preferências: uso de conector prototípico (embora); ordem intercalada; impossibilidade de inversão; contrastiva factual; domínio epistêmico; verbo da principal no presente do indicativo ligado a um sintagma adjetivo; e, polaridade afirmativa em ambas as orações e essas expressões com valor concessivo funcionam como um adjunto introduzido por um conector concessivo prototípico.

O funcionamento dessas expressões concessivas introduzidas por conectores normalmente utilizados em complexos subordinativos ainda necessita de mais pesquisas para compreensão de sua natureza sintática.

\subsection{As construções concessivas e os fatores extra-lingüísticos}

\subsubsection{Tipo de autor ${ }^{20}$}

O uso que os autores das cartas dos jornais oitocentistas fazem do tipo de conector, foi mapeado conforme o quadro a seguir:

\begin{tabular}{|l|c|c|c|}
\hline \multirow{2}{*}{ Conector } & \multicolumn{2}{|c|}{ Tipo de Autor } & TOTAL \\
\cline { 1 - 3 } & Leitor & Redator & \\
\hline Ainda que & 12 & 12 & 24 \\
\hline Ainda quando & 2 & 1 & 3 \\
\hline Embora & 16 & 14 & 30 \\
\hline Mesmo que & 1 & 0 & 1 \\
\hline Nem que & 0 & 1 & 1 \\
\hline Por mais que & 3 & 0 & 3 \\
\hline Por menos que & 0 & 1 & 1 \\
\hline Posto que & 2 & 2 & 4 \\
\hline (Se ) bem que & 4 & 6 & 10 \\
\hline TOTAL & 40 & 37 & 77 \\
\hline
\end{tabular}

20 Salvo as tabelas 10 e 11 , as demais análises englobam a totalidade das ocorrências, independentemente de introduzirem ou não construção concessiva com verbo flexionado. 
A quantidade de conectores concessivos usados por leitores e por redatores relaciona-se à verificação do conhecimento desse recurso argumentativo por parte dos profissionais em jornalismo que, em tese, estariam mais habituados a desenvolver textos argumentativos, em comparação aos leitores que supostamente teriam menos experiência na elaboração de textos.

Com os dados levantados, percebemos que a diferença entre o uso por leitores e redatores é quase inexistente, o que refuta a hipótese levantada anteriormente, de que a construção concessiva seria um recurso argumentativo mais requintado e, por conseguinte, utilizado mais por profissionais que estivessem habituados a esse tipo de produção.

\begin{tabular}{|l|l|l|c|}
\hline \multirow{2}{*}{ Tipo de autor } & \multicolumn{2}{|c|}{ Freqüência } & TOTAL \\
\cline { 2 - 3 } & Subjuntivo & Indicativo & \\
\hline Leitor & $24 / 30=80 \%$ & $6 / 30=20 \%$ & $30 / 59=50 \%$ \\
\hline Redator & $26 / 29=89 \%$ & $3 / 29=10 \%$ & $29 / 59=49 \%$ \\
\hline TOTAL & $\mathbf{5 0 / 5 9 = 8 4 \%}$ & $\mathbf{9 / 5 9 = 1 5 \%}$ & $\mathbf{5 9 / 5 9 = 1 0 0 \%}$ \\
\hline Tabela 10: Tipo de autor e uso de modo verbal &
\end{tabular}

Os cálculos de freqüência para este item mostram que existe um equilíbrio no uso dos modos verbais do subjuntivo e do indicativo pelos leitores e pelos redatores. Em uma situação de uso da língua que considerasse o emprego de modo verbal pelo falante/autor como critério para verificar o uso da norma culta, não poderia ser aplicado esse tipo de distinção no corpus sob análise, o que demonstra também que essa é uma estrutura lingüística que não se relaciona a nenhum fator social.

\subsubsection{Período do século XIX}

As cartas que compõem o corpus sob análise foram distribuídas em três conjuntos, correspondentes a três fases históricas, conforme foi detalhado na seção 3.1. A intenção de mapear o uso dos conectores concessivos em cada uma das fases e verificar se existe uma relação entre o uso de determinado conector e o momento histórico, assim como o modo verbal empregado prioritariamente, têm o objetivo de verificar se cada um dos conectores concessivos extraídos do corpus foi utilizado com a mesma freqüência no decorrer do século XIX. 
Na primeira tabela, temos informações estatísticas sobre o uso do modo verbal nas construções concessivas durante o século XIX:

\begin{tabular}{|l|c|c|c|}
\hline \multirow{2}{*}{ Período do século XIX } & \multicolumn{2}{|c|}{ Freqüência } & TOTAL \\
\hline Subjuntivo & Indicativo & \\
\hline De 1808 a 1840 & $14 / 21=66 \%$ & $7 / 21=33 \%$ & $21 / 59=35 \%$ \\
\hline De 1841 a 1870 & $18 / 19=94 \%$ & $1 / 19=5 \%$ & $19 / 59=32 \%$ \\
\hline De 1871 a 1900 & $18 / 19=94 \%$ & $1 / 19=5 \%$ & $19 / 59=32 \%$ \\
\hline $\begin{array}{l}\text { TOTAL } \\
\text { Tabela 11: Uso do modo subjuntivo no século XIX }\end{array}$ & $\mathbf{9 / 5 9 = 1 5 \%}$ & $\mathbf{5 9 / 5 9 = 1 0 0 \%}$ \\
\hline
\end{tabular}

A informação mais importante da tabela não é a da divisão por períodos, propriamente dita, mas a supremacia de uso do modo subjuntivo durante o século XIX, mostrando a seguinte tendência: conector + verbo no modo subjuntivo.

O quadro seguinte tem o objetivo de mostrar se o uso de algum conector que introduz construções concessivas permanece igual durante o século XIX.

\begin{tabular}{|l|c|c|c|c|}
\hline \multicolumn{1}{|c|}{ CONECTOR CONCESSIVO } & \multicolumn{4}{c|}{ PERÍODO HISTÓRICO } \\
\hline Ainda que/ Ainda quando & $\begin{array}{c}\text { FASE 1 } \\
(\mathbf{1 8 0 8 - 1 8 4 0 )}\end{array}$ & $\begin{array}{c}\text { FASE 2 } \\
(\mathbf{1 8 4 1 - 1 8 7 0 )}\end{array}$ & $\begin{array}{c}\text { FASE 3 } \\
(\mathbf{1 8 7 1 - 1 9 0 0 )}\end{array}$ & TOTAL \\
\hline Embora & 12 & 8 & 7 & 27 \\
\hline Mesmo que & 6 & 10 & 14 & 30 \\
\hline Nem que & 1 & - & - & 1 \\
\hline Por mais que / Por menos que & - & - & 1 & 1 \\
\hline Posto que & 1 & 1 & 2 & 4 \\
\hline (Se) bem que & 1 & 2 & 1 & 4 \\
\hline TOTAL & 3 & 4 & 3 & 10 \\
\hline
\end{tabular}

Os dados de língua falada na variedade padrão coletados para o projeto NURC e analisados no trabalho de Neves (1999, p. 573), mostram que o uso do ainda que diminuiu para 3 ocorrências de 55 (5,45\%) e o embora aumentou para 26 ocorrências de 55 (47,27\%).

O número de ocorrências de conectores concessivos em cada fase do século XIX permanece estável, a não ser pelos indícios do uso ascendente do embora (6/10/14) e do uso descendente do ainda que (12/8/7) no decorrer do século XIX.

A observação desses fatores extralingüísticos permitiu analisar que 0 corpus em análise não favorece uma caracterização e uma contribuição desses fatores para o uso nos complexos concessivos. 


\section{Considerações Finais}

Esta pesquisa teve como objetivo geral apresentar uma descrição do uso e do funcionamento das construções concessivas em cartas de leitores e de redatores dos jornais oitocentistas brasileiros.

Para isso, procuramos adotar uma perspectiva de análise lingüística que levasse em consideração não somente os critérios sintáticos, mas que abrangesse também critérios semânticos e pragmáticos para descrição do uso da língua.

A teoria sistêmica de Halliday (1994), apresentada no primeiro capítulo serviu como um organizador geral para os itens que deveriam ser analisados com finalidade de uma descrição, ou seja, a "estrutura" da teoria sistêmica foi utilizada, porém o "conteúdo" foi selecionado com base em elementos que se mostraram mais produtivos para a descrição das construções concessivas.

O segundo capítulo apresentou uma revisão bibliográfica das diversas abordagens sobre as construções concessivas, sob duas perspectivas: a dos estudos normativos e a dos estudos descritivos. Nos estudos normativos existem leves apontamentos sobre possíveis análises que poderiam ser feitas a respeito das construções concessivas e que extrapolam os objetivos das obras normativas. Os estudos descritivos apresentados utilizam-se de determinadas ferramentas para análise das construções concessivas, que foram aproveitadas para a nossa descrição, além dos resultados apresentados e do funcionamento dessas construções.

No terceiro capítulo tratamos não só da metodologia utilizada para o tratamento dos dados sobre as construções concessivas, mas principalmente da natureza do corpus escolhido para a análise. A importância do gênero escolhido, os graus de formalidade das cartas, a influência da intenção discursiva são elementos que contribuem para a visão sistêmica do funcionamento da língua que adotamos neste trabalho, por isso o corpus não foi tratado somente como uma "mina de dados", mas levamos em conta as "riquezas dessa mina", de informações, ao considerarmos o contexto de produção.

A descrição, a interpretação e a análise dos dados foram apresentadas no quarto capítulo, que foi dividido em três partes: orações concessivas, 
expressões concessivas e contexto de produção e uso das cartas argumentativas. Para expormos os resultados da descrição das construções concessivas nos jornais do século XIX, precisamos antes resgatar o modelo sistêmico de Halliday.

A Função Ideacional do modelo sistêmico de Halliday é aquela que faz uma representação do mundo, por meio de papéis dos elementos da oração, que denominaremos de atribuição sintática do uso da língua.

\begin{tabular}{|c|c|}
\hline FUNÇÃO SISTÊMICA & REPRESENTAÇÃO \\
\hline Função Ideacional & 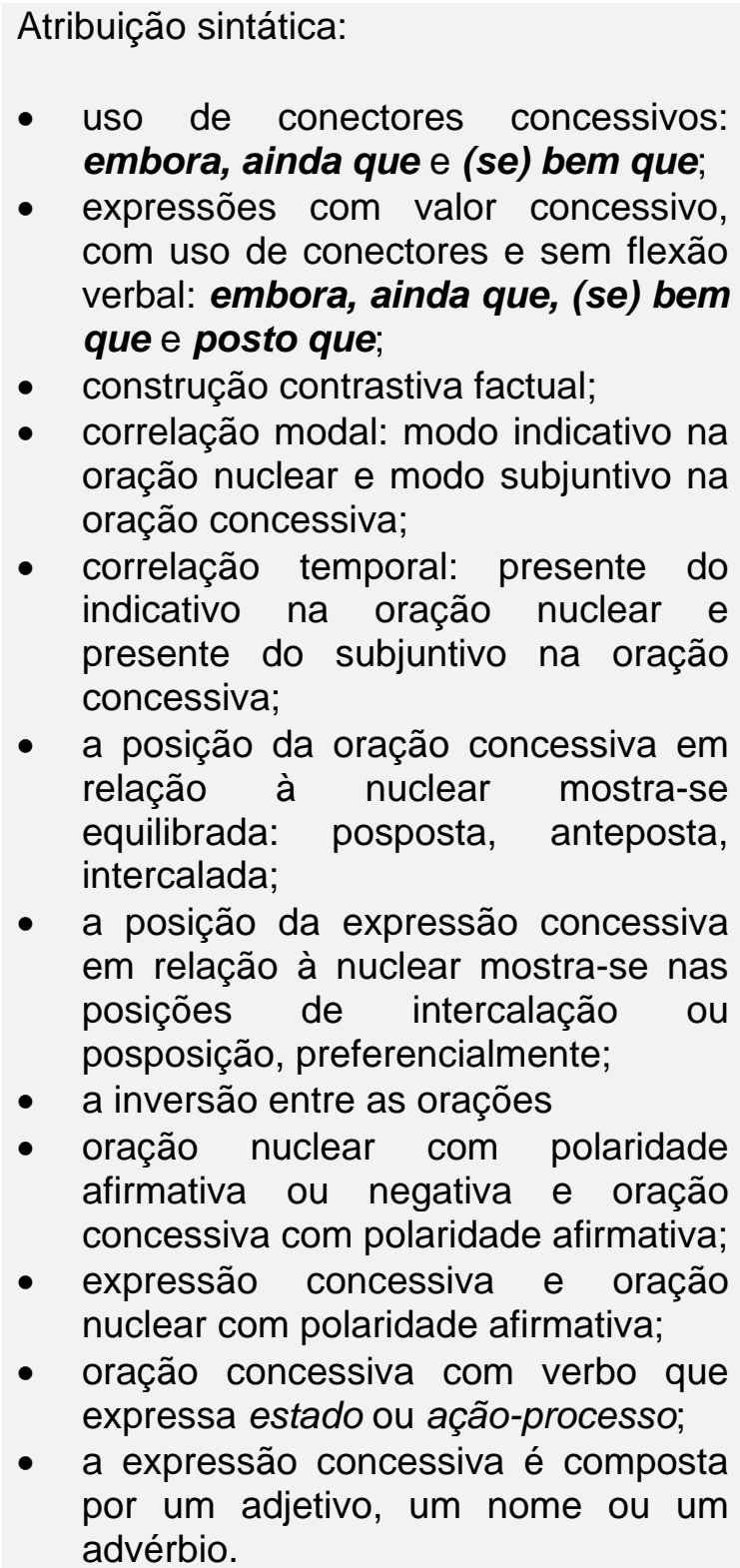 \\
\hline
\end{tabular}


Os resultados apresentados no quadro acima correspondem à maior porcentagem de uso das concessivas no corpus e referem-se às características sintáticas dessas construções.

A Função Interpessoal integrante do modelo sistêmico adotado tem por objetivo codificar a troca interacional, por isso pressupõe as relações que o falante/autor estabelece no uso da linguagem.

\begin{tabular}{|l|l|}
\hline \multicolumn{1}{|c|}{ FUNÇÃO SISTÊMICA } & \multicolumn{1}{c}{ REPRESENTAÇÃo } \\
\hline Função Interpessoal & $\begin{array}{l}\text { Interação: } \\
\text { o caráter híbrido dos graus de } \\
\text { formalidade das cartas de jornais } \\
\text { (língua escrita com características da } \\
\text { língua falada, como mostra o gráfico } \\
1) ; \\
\text { predomínio do domínio epistêmico }\end{array}$ \\
& $\begin{array}{l}\text { que ressalta os processos mentais } \\
\text { que o falante/autor estabelece para a } \\
\text { argumentação e uma provável } \\
\text { resposta não-lingüística; }\end{array}$ \\
& $\begin{array}{l}\text { gênero textual (carta argumentativa) } \\
\text { com função discursiva de persuasão; } \\
\text { concessão no monólogo. }\end{array}$
\end{tabular}

A Função Textual é aquela que especifica as relações dentro do enunciado e entre o enunciado e a situação, transmitindo uma mensagem que, no caso das construções concessivas, é classificada como rema (corpo da mensagem: oração ou expressão concessiva) que se apóia na estrutura da mensagem, o tema (oração nuclear). O sistema de tema-rema, muitas vezes se sobrepõe ao de dado (informação dada) e novo (informação nova), na organização textual da linguagem.

\begin{tabular}{|c|c|}
\hline FUNÇÃO SISTÊMICA & REPRESENTAÇÃO \\
\hline Função Textual & $\begin{array}{l}\text { Contexto: } \\
\text { - cartas de leitores e de redatores } \\
\text { como expressão de opinião a um } \\
\text { tema já mencionado; } \\
\text { - argumentação no âmbito público. }\end{array}$ \\
\hline
\end{tabular}

As respostas às perguntas que nos propusemos a responder nessa descrição estão resumidas nos quadros acima, porém resta a certeza de que, se, por um lado algumas perguntas foram respondidas, por outro lado mais 
perguntas vieram à tona, como por exemplo, a caracterização de um adjunto com valor concessivo ou ainda um conector especificamente subordinativo introduzir um adjunto adverbial.

Com a análise de elementos lingüísticos e extra-linguisticos relativos às construções concessivas, esperamos que a descrição do uso dessas construções no século XIX tenha contribuído para os estudos sobre a história do Português Brasileiro. 


\section{Referências Bibliográficas}

BAKHTIN, M. Estética da criação verbal. [tradução feita a partir do francês por Maria Ermantina Galvão G. Pereira] 2. ed., São Paulo: Martins Fontes, 1997.

BARBOSA, A. \& LOPES, C. R. (orgs.). Críticas, queixumes e bajulações na Imprensa Brasileira do séc. XIX: cartas de leitores e cartas de redatores. Rio de Janeiro: Faculdade de Letras/UFRJ/Labor-Histórico, 2004. (versão eletrônica)

BECHARA, E. Moderna gramática portuguesa. 37. ed. Rio de Janeiro: Lucerna, 2003.

BORBA, F. S. (coord.) Dicionário gramatical de verbos do Português Contemporâneo do Brasil. 2. ed. São Paulo: Fundação Editora da Unesp, 1990.

CUNHA, C. F. \& CINTRA, L. F. L. Nova gramática do português contemporâneo. 2. ed., Rio de Janeiro: Nova Fronteira, 1985.

DECAT, M. B. N. Relações adverbiais e gênero do discurso. In: KOCH, I. G. V. (org.) Caderno de Estudos Lingüísticos. № 28, 1995, p. 19-35.

HALLIDAY, M. A. K. An introduction to Functional Grammar. 2. ed. London/Melbourne/Auckland, Edward Arnold, 1994.

KAUFMAN, A. M. \& RODRÍGUEZ, M. E. Escola, leitura e produção de textos. Porto Alegre: Artmed Editora, 1995.

LIMA, H. R. V. Uma abordagem teórica da concessão, D.E.L.T.A. 3/2, 1987, p.139-161.

LUFT, C. P. Moderna gramática brasileira. 8. ed. Rio de Janeiro, Globo, 1987. MACAMBIRA, J. R. A estrutura morfo-sintática do português: aplicação do estruturalismo lingüístico. 3. ed. São Paulo, Pioneira, 1978.

MATTHIESSEN, C. e THOMPSON, S. The structure of discourse and 'subordination'. In: THOMPSON, S. e HAIMAN, J. Clause combining in grammar and discourse. Amsterdam/Philadelphia: John Benjamins Publishing Company, 1988, p. 275-330.

MIRA MATEUS, M. H. et al. Gramática da Língua Portuguesa. Coimbra: Almedina, 1983. 
NEVES, M. H. M. A Gramática Funcional. São Paulo: Martins Fontes, 1997.

NEVES, M. H. M. As construções concessivas. In: NEVES, M. H. M. (org.) Gramática do português falado - vol VII: novos estudos. 2. ed., São Paulo: Humanitas/FFLCH/USP; Campinas: Editora da Unicamp, 1999, p. 545-591.

NEVES, M. H. M. Gramática de usos do português. São Paulo: Editora da Unesp, 2000.

NEVES, M. H. M. A gramática: história, teoria e análise, ensino. São Paulo, Editora da Unesp, 2002.

OESTERREICHER, W. Gesprochene Sprache und geschriebene Sprache (Langage parlé et langage écrit) In: HOLTUS, G., METZELTIN, M. \& SCHMITT, C. (Hrsg.). Lexikon der Romanistischen Linguistik. Band 1, Tübingen, Niemeyer, 2000.

ROCHA LIMA, C. H. da. Gramática normativa da língua portuguesa. 22. ed. Rio de Janeiro, José Olympio, 1982.

RODRIGUES, A. C. S. et alii. "Correlação modo-temporal nas construções complexas do português culto falado no Brasil: orações concessivas". In: NEVES, M.H. DE M. (org.) Gramática do Português falado - vol. VII: novos estudos. 2. ed., São Paulo: Humanitas/FFLCH/USP; Campinas: Editora da Unicamp, 1999, p. 653-672.

SAID ALI, M. Gramática secundária e Gramática Histórica da Língua Portuguesa.

3. ed. revista e ampliada, Brasília, Editora da Universidade de Brasília, 1964. SWEETSER, E. From etymology to pragmatics: metaphorical and cultural aspects of semantic structure. New York, Cambridge, 1990. 